\title{
Multiculturaliteit in het Nederlandse strafrecht
}

\author{
Hein Wolswijk*
}

\section{Inleiding}

De term 'cultuur' wordt in verschillende betekenissen gebruikt. In verband met multiculturaliteit verwijst cultuur naar 'een bijzondere levenswijze, verbonden aan een bepaalde groep, klasse of tijdperk'. ' Wat betreft de Nederlandse multiculturele samenleving gaat het, naast de autochtone cultuur, vooral om de bijzondere levenswijzen van groepen die (oorspronkelijk) afkomstig zijn uit Turkije en uit Afrikaanse, Latijns-Amerikaanse en Aziatische landen. Vele met die levenswijzen samenhangende gedragingen zijn strafrechtelijk irrelevant; sommige zijn dat - prima facie wel. Bekende voorbeelden zijn eerwraakzaken (levensberovingen of geweldgebruik voortvloeiend uit gekrenkte persoonlijke of familie-eer), meisjesbesnijdenis, het dreigen magische krachten op een ander over te brengen en bijzondere begrafenisrituelen.

Doel van dit preadvies is te laten zien hoe het Nederlandse strafrecht met dergelijke gedragingen 'omgaat', hoe het deze beoordeelt. Geldt voor (sommige van) deze gedragingen specifieke wetgeving? Is bijvoorbeeld eerwraak afzonderlijk, als zelfstandig delict, strafbaar gesteld? Zo nee, onder welke (commune) strafbepaling valt deze gedraging dan? Impliceert het doden van een ander met een eerwraakmotief steeds dat de dader met voorbedachte raad heeft gehandeld en dus schuldig is aan moord? Kan bedreiging met het aanwenden van dodelijke spirituele krachten worden aangemerkt als 'bedreiging met geweld'? Zijn culturele minderheidsopvattingen relevant voor de vraag of een gedraging 'ontuchtig' is? Als de gedraging onder een strafbepaling valt, rijst de vraag of cultuur een rol speelt bij de strafuitsluitingsgronden. Heeft bijvoorbeeld een beroep op psychische overmacht vanwege de druk die de dader 'vanuit zijn cultuur' ervoer kans van slagen? En is cultuur een factor bij de straftoemeting?

\footnotetext{
* Hein Wolswijk is universitair hoofddocent strafrecht aan de Rijksuniversiteit Groningen.

I. C.J.M. Schuyt, Publiekrecht in een multiculturele samenleving, in: Multiculturaliteit en recht, Handelingen NJV, $138^{\mathrm{e}}$ jaargang, 2008-I, Deventer: Kluwer 2008, p. 69.
} 
Veel van deze vragen zijn voor de juridische praktijk niet nieuw. Zo heeft de Nederlandse rechter al decennialang te oordelen over gevallen van eerwraak. Ook de rechtswetenschap houdt zich al sinds geruime tijd bezig met vraagstukken van cultuur en strafrecht. Het is voorwerp van onderzoek in tal van artikelen, ${ }^{2}$ annotaties $^{3}$ en proefschriften. ${ }^{4,5}$

Het preadvies is als volgt opgebouwd. Eerst worden enkele opmerkingen gemaakt over de begrippen cultureel delict, cultureel verweer en cultuur (par. 2) en over het juridische kader (par. 3). Vervolgens wordt bezien in hoeverre cultuur direct zichtbaar is in de (straf)wetgeving (par. 4). Daarna wordt uitgebreid ingegaan op de vraag welke rol cultuur speelt bij, achtereenvolgens, het bewijs (par. 5), de interpretatie van delictsbestanddelen (par. 6), de strafuitsluitingsgronden (par. 7) en ten slotte de straftoemeting (par. 8).

\section{Cultureel delict, cultureel verweer, cultuur}

Cultureel delict

Gedragingen zoals eerwraak en meisjesbesnijdenis worden wel culturele delicten genoemd. Strijbosch omschrijft culturele delicten als 'gedragingen, strafbaar volgens ons strafrecht, maar toelaatbaar volgens intern recht van de sociale groep - meestal een migrantengroep - waartoe de justitiabele behoort'. ${ }^{6}$ Een iets ruimere omschrijving hanteert 't Hart, wanneer hij spreekt van 'strafbare gedragingen die binnen die sociale groep zo niet toelaatbaar worden geacht, dan toch wel anders - hetzij lichter, hetzij ernstiger - worden beoordeeld' ${ }^{7}$ Bij deze omschrijvingen is het uitgangspunt derhalve dat de gedraging in beginsel strafbaar naar Nederlands recht is (het is een delict, valt dus onder een strafbepaling). Daarmee worden vragen over de invloed van cultuur op het strafrecht meteen verlegd naar het terrein van de strafuitsluitingsgronden en de straftoemeting.

2. Zie onder meer R.H. Wormhoudt, Culturele achtergronden: strafuitsluitingsgronden?, Proces I986, p. 329-336; W. Huisman, Culturele delicten, Proces 1995, p. 80-88; S. Bloemink, Cultureel verweer, in: G. Anders e.a. (red.), De onvermijdelijkheid van rechtspluralisme, Nijmegen: Ars Aequi Libri 1998, p. 53-68; C.W. Maris van Sandelingenambacht, Wie is de vader, wie is de dader?, NJB 200I, p. I708I7I2; M. Bovens, Cultuur als verweer, in: F. Bovenkerk e.a. (red.), Multiculturaliteit in de strafrechtspleging, Den Haag: Boom Juridische uitgevers 2003, p. I37-I5O; H.D. Wolswijk, Cultuur en strafbaarheid, RM Themis 2004, p. 257-266.

3. Met name door A.C. 't Hart, zie bijvoorbeeld zijn noten onder HR ig april I988, NJ I989, I40, HR I8 september I989, NJ I990, 29 I.

4. H.C. Wiersinga, Nuance in benadering, culturele factoren in het strafproces, Den Haag: Boom Juridische uitgevers 2002; M.G.J. Post, Detentie en culturele diversiteit, Den Haag: Boom Juridische uitgevers 2005; M. Siesling, Multiculturaliteit en verdediging in strafzaken, Den Haag: Boom Juridische uitgevers 2006; J.M. ten Voorde, Cultuur als verweer, Een grondslagentheoretische studie naar de ruimte en grenzen van culturele diversiteit in enige leerstukken van materieel strafrecht, Nijmegen: Wolf Legal Publishers 2007.

5. En, niet te vergeten, 'Multiculturaliteit en recht' was dit jaar het onderwerp van de preadviezen en de jaarvergadering van de NJV (zie noot I).

6. F. Strijbosch, Culturele delicten in de Molukse gemeenschap, NJB I99I, p. 666.

7. Noot onder HR 26 mei I992, NJ I992, 568. 


\section{Cultureel verweer}

Een omschrijving van cultureel verweer die aansluit bij deze definities van een cultureel delict is: een verweer waarbij de dader van het culturele delict zich beroept op het gegeven dat zijn gedraging toelaatbaar is volgens de normen van de sociale groep. De strekking van een dergelijk beroep kan zeer verschillend zijn. In zijn meest eenvoudige vorm valt de strekking samen met de zojuist gegeven omschrijving van cultureel verweer: het enkele gegeven dat de gedraging toelaatbaar is volgens de 'eigen' normen is tevens grond voor straffeloosheid of strafvermindering. Voor alle andere vormen - andere strekkingen - van een cultureel verweer geldt dat het verweer moet worden 'aangekleed'. De strekking kan bijvoorbeeld zijn dat de gedraging niet alleen toelaatbaar is volgens de normen van de sociale groep, maar dat van dat gegeven, of van de groep, tevens een druk uitging om de gedraging te verrichten, welke druk des daders wilsvrijheid aantastte en daarom tot straffeloosheid of strafvermindering zou moeten leiden ('volitief verweer'). Het verweer kan ook gekoppeld zijn aan onbekendheid met de strafrechtsnormen ('cognitief verweer'). Hier is wel heel duidelijk dat het culturele verweer nader moet worden omschreven. Toelaatbaarheid volgens de eigen normen impliceert op zichzelf immers geenszins onbekendheid met de strafrechtsnormen (en nog minder dat die onbekendheid verontschuldigbaar is).

Als gezegd is bij deze omschrijvingen van cultureel delict en cultureel verweer de focus geheel gericht op de strafuitsluitingsgronden. Het preadvies beperkt zich daar niet toe. Vragen omtrent de invloed, de doorwerking van cultuur doen zich ook voor bij de strafbepalingen, op bestanddeel-niveau (zie par. I). Het gaat dus niet alleen om culturele delicten, maar ook om culturele gedragingen die wellicht delictueel zijn.

\section{Cultuur}

Het begrip cultuur roept de meeste vragen op. In de inleiding is gesproken van cultuur als een bijzondere levenswijze, verbonden aan een bepaalde groep. Dat is een omschrijving die aansluit bij de zojuist gegeven omschrijvingen van het culturele delict en het culturele verweer. Deze omschrijvingen zijn weinig problematisch. Cultuur staat voor een levenswijze, voor de normen van een sociale groep - niet minder, maar vooral niet méér. Vaststelling van die levenswijze en/of normen kan lastig zijn, maar dat hoeft zeker niet. Lastig wordt het pas wanneer, bijvoorbeeld, de vraag wordt gesteld - zie het genoemde voltitieve culturele verweer - op welke wijze het normenstelsel van een sociale groep, of die groep zelf, van invloed is op iemands handelen? Wat 'doet' cultuur eigenlijk?

Daarover wordt verschillend gedacht. Er bestaan vele, zeer uiteenlopende opvattingen. ${ }^{8}$ Aan het ene eind van het spectrum staat het essentialistische (ook wel: culturalistische) cultuurbegrip. In de essentialistische visie is cultuur een vaststaand gegeven, waaraan een dwingende kracht wordt toegekend en waaraan men zich niet

8. Zie hierover S. Tempelman, Duiken in het duister: een gematigd constructivistische benadering van culturele identiteit, Migrantenstudies 1999, p. 70-82. 
kan onttrekken. Cultuur is een 'ding' dat onafhankelijk is van veranderende omstandigheden. Eenvoudig gezegd: mensen en hun gedragingen zijn slechts een product van cultuur ('my culture made me do it'). Aan het andere eind van het spectrum van opvattingen staat het constructivistische standpunt. In die opvatting is cultuur juist het resultaat van het proces van interactie waarmee mensen betekenis geven aan hun wereld. Cultuur is niet een onveranderlijk gegeven, maar wordt door mensen zelf - meer of minder bewust - gemaakt. Cultuur is dan een product van de mens. Tegenwoordig wordt veelal een tussenpositie verdedigd: het gematigd constructivisme. Enerzijds is cultuur een product van menselijk (samen)handelen, anderzijds kan cultuur ook niet zo maar worden 'afgelegd' en stuurt cultuur iemands handelen.

De onduidelijkheid over het begrip cultuur levert in die zin een probleem op, dat de gebruikte definitie vanzelfsprekend (mede)bepalend is voor het antwoord op de vraag naar de invloed van cultuur op het strafrecht. Voor de hand ligt, dat de essentialistische visie meer juridische relevantie heeft - in ieder geval voor zover het gaat om de invloed ervan op iemands handelen - dan de (gematigd) constructivistische. In een extreem essentialistische variant is de invloed van cultuur op iemands handelen misschien wel zodanig dat van enig wilselement in het geheel geen sprake is. Een strafrechtelijke norm die ingaat tegen een culturele norm zou dan voor de culturele dader eigenlijk geen betekenis hebben. Hij zou niet eens een strafrechtelijk relevante gedraging verrichten (vergelijkbaar met iemand die handelt onder hypnose) of anders vanwege psychische overmacht vrijuit moeten gaan. In dit cultuurdebat kan hier vanzelfsprekend geen stelling worden genomen. Dat betekent dat het in het onderstaande steeds gaat om de mogelijke invloed van cultuur.

\section{Juridisch kader}

Nationaal (Nederlands) strafrecht

De Nederlandse strafrechter past alleen Nederlands strafrecht toe. De culturele achtergrond van de dader of de daad is op de toepasselijkheid daarvan niet van invloed. De in het multiculturele debat nogal eens verkondigde stelling dat in Nederland iedereen zich heeft te gedragen naar het Nederlandse strafrecht ('when in Rome ...') is juist. Art. 2 Sr bepaalt immers dat de Nederlandse strafwet toepasselijk is op ieder die zich in Nederland aan enig strafbaar feit schuldig maakt, en maakt daarbij dus geen onderscheid naar cultuur of culturele achtergrond. Sterker nog, ook buiten Nederland heeft men zich soms naar de Nederlandse strafwet te gedragen en uit de regeling van deze extraterritoriale rechtsmacht (art. 3 e.v. Sr) blijkt dat cultuur hier evenmin een relevante factor is. ${ }^{9}$ Het verweer dat het Nederlandse strafrecht niet van toepassing is vanwege, bijvoorbeeld, de culturele achtergrond van de dader, heeft dus geen kans van slagen. De strafrechtelijke regels zijn voor de culturele dader niet anders, zodat culturele aspecten alleen binnen die regels betekenis kunnen hebben.

9. Dat kan anders liggen bij de overname van strafvervolging door Nederland voor zover Nederland geen 'originaire' rechtsmacht heeft. Verbondenheid met de 'Nederlandse cultuur' zou reden kunnen zijn voor overname van de strafvervolging. 
Aan deze stand van zaken zal, als het aan het Nederlandse kabinet ligt, geen verandering komen, ook niet op andere rechtsgebieden:

'Van rechtspluralisme, in de zin van heterogene rechtsstelsels die naast elkaar staan,
kan in Nederland geen sprake zijn. Voor het straf- en het bestuursrecht ligt dat voor de
hand, omdat hierin de relaties geregeld worden tussen staat en burger, en de staat geen
onderscheid maakt naar soorten burgers. Voor het civiele recht, en zeker het verbinte-
nissen- en het personen- en familierecht, geldt dat er geen enkele reden voor een der-
gelijk pluralisme is.'

Een grondwettelijk of verdragsrechtelijk '(mensen)recht op cultuur'?

Grondwet en verdragen (er)kennen diverse mensenrechten, zoals de vrijheid van godsdienst en de vrijheid van meningsuiting. Deze rechten kunnen strafrechtelijk relevant zijn: een strafbepaling die een niet-gerechtvaardigde inbreuk maakt op een mensenrecht dient buiten toepassing te worden gelaten. Evenzo kan (moet) bij de interpretatie van delictsbestanddelen rekening worden gehouden met mensenrechten (bij bijvoorbeeld belediging). Indirect kunnen deze rechten voor ons onderwerp natuurlijk van belang zijn, bijvoorbeeld indien iemands gedraging niet alleen cultuurbepaald is maar ook voortvloeit uit diens godsdienst. De Nederlandse wetgeving kent echter geen zelfstandig 'recht op cultuur' of 'recht op culturele identiteit'. In het Europees Verdrag voor de Rechten van de Mens (EVRM) is evenmin een dergelijk recht opgenomen. Voorstellen voor een Additioneel Protocol bij het EVRM inzake Rechten op Cultureel Terrein hebben het om een aantal redenen niet gehaald. In het bijzonder werd een recht op culturele identiteit verworpen omdat het niet afdwingbaar was vanwege de vaagheid van het begrip culturele identiteit en omdat het geen bescherming zou toevoegen aan de rechten van het EVRM. Ook zou een recht op culturele identiteit kunnen worden uitgelegd als een ondersteuning van bedenkelijke culturele activiteiten. ${ }^{\text {II }}$ Verdragsrechtelijk komt art. 27 van het Internationaal Verdrag inzake Burgerrechten en Politieke Rechten het dichtst in de buurt van een recht op cultuur:

'In Staten waar zich etnische, godsdienstige of linguïstische minderheden bevinden, mag aan personen die tot die minderheden behoren niet het recht worden ontzegd, in gemeenschap met de andere leden van hun groep, hun eigen cultuur te beleven, hun eigen godsdienst te belijden en in de praktijk toe te passen, of zich van hun eigen taal te bedienen.'

Onduidelijk is echter wat de reikwijdte van deze bepaling is. ${ }^{\mathrm{I2}}$ Wat wordt verstaan onder het recht de eigen cultuur te beleven? Heeft het wel zelfstandige betekenis naast andere rechten? En is dit een recht dat aan individuen toekomt of aan groepen?

Io. Kamerstukken II 2006-2007, 30800 VI, nr. II5, p. 24.

II. Zie hierover Y.M. Donders, Towards a Right to Cultural Identity, Antwerpen: Intersentia 2002, p. 262 e.v.

I2. Opgemerkt zij dat de beslissingen van het Mensenrechtencomité, anders dan de uitspraken van het Europese Hof voor de Rechten van de Mens, niet bindend zijn. 
Deze (staats- en internationaalrechtelijke) vragen blijven hier onbesproken. Zeker is wel dat een 'recht op cultuur' tot dusver in strafzaken geen rol heeft gespeeld.

\section{$4 \quad$ Cultuur en (straf)wetgeving}

\section{I Strafbepalingen en strafuitsluitingsgronden}

\section{Weinig 'culturele kleur'}

In hoeverre is cultuur direct 'zichtbaar' in de (straf)wetgeving? Komen culturele delicten, zoals (meisjes)besnijdenis, als zodanig voor in de strafwet? Dat is nauwelijks het geval. In het Nederlandse strafrecht is, in de woorden van Wiersinga, 'weinig autochtone, culturele kleur' te vinden. ${ }^{\mathrm{I} 3} \mathrm{Zij}$ bedoelt dat daarin weinig delicten zijn opgenomen, die feitelijk eigenlijk alleen vanuit een niet-Nederlandse culturele achtergrond worden gepleegd en daarom bij uitstek culturele delicten kunnen worden genoemd. Schaking (art. 28I Sr) is een van de weinige voorbeelden van dergelijke, feitelijk gezien, culturele delicten. Dit delict is immers verbonden met het fenomeen van het gearrangeerde huwelijk en dat komt in de autochtone Nederlandse cultuur niet meer voor. ${ }^{\mathrm{I}}{ }^{4}$ Een voorbeeld is wellicht ook bigamie. Andere culturele (strafbare) gedragingen daarentegen, zoals meisjesbesnijdenis en eerwraak, zijn niet afzonderlijk strafbaar gesteld, maar vallen onder algemene strafbepalingen ((zware) mishandeling, doodslag). Ook bij de strafuitsluitingsgronden ziet men die culturele kleur niet.

Geen zelfstandige strafbaarstelling van meisjesbesnijdenis

Ten aanzien van enkele culturele gedragingen, die zonder meer onder een bestaande delictsomschrijving ressorteren, is punt van discussie of deze niet een afzonderlijke strafbaarstelling 'verdienen'. Het belangrijkste voorbeeld is meisjesbesnijdenis, een gedraging die strafbaar is als (zware) mishandeling krachtens de art. 300-303 Sr. Het debat omtrent een afzonderlijke strafbaarstelling dateert al van het begin van de jaren negentig. Vooropgesteld zij dat vanzelfsprekend door niemand wordt beweerd dat de enkele invoering van een zelfstandige strafbaarstelling voldoende is ter beteugeling van het probleem. Het belangrijkste argument van de voorstanders lijkt te zijn de noodzaak tot een heldere normstelling (daarmee recht doend aan het lex certagebod). In het verlengde daarvan ligt het argument dat minder ruimte is voor een geslaagd beroep op verontschuldigbare dwaling omtrent de wederrechtelijkheid van besnijdenis. Een specifieke strafbaarstelling zou ook aangeven dat niet snel sprake is van een rechtens te honoreren, uit de cultuur voortkomende druk die psychische overmacht oplevert. ${ }^{15}$ Tegenstanders, waaronder de wetgever, ${ }^{16}$ stellen daar tegen-

I3. H. Wiersinga, De standaard van het strafrecht in een multiculturele samenleving, in: K. Lünneman e.a. (red.), De onzichtbare standaard in het recht, Deventer: Gouda Quint I999, p. 138.

I4. Zie hierover ook H.C. Wiersinga, Schaking als cultureel delict, in: R. Haveman e.a. (red.), Sex, zeden en strafrecht, 2000, p. I67-I85.

15. Zie bijv. R. Kool, Strafbaarstelling en handhaving van meisjesbesnijdenis, NJB 2005, p. 2092 e.v., met reactie van $H$. Weyers, Strijd tegen meisjesbesnijdenis: een schromelijke overschatting van de betekenis van recht, NJB 2006, p. 263 e.v. (met naschrift van Kool).

I6. Zie Kamerstukken II 2004, 22894, 
over dat een specifieke strafbaarstelling niet nodig is om duidelijk te maken dat besnijdenis strafbaar is. Verder wordt wel eens betoogd dat specifieke strafbaarstelling de dialoog met de migrantengemeenschappen zou kunnen bemoeilijken, omdat zij zich als gemeenschap aangevallen kunnen voelen. ${ }^{\mathrm{I}}$

\section{Eerwraakmotief is geen wettelijke strafuerzwarende omstandigheid}

Eer-gerelateerd geweld valt onder de levensdelicten (moord, doodslag) of onder de geweldsdelicten ((zware) mishandeling). Ook bij dit onderwerp bestaat verschil van mening over de vraag of specifieke wettelijke voorzieningen vereist zijn. De discussie is hier echter deels een andere dan bij besnijdenis. Ten eerste zou de voorziening, anders dan bij besnijdenis, geen betrekking hebben op een bepaalde gedraging, maar op een bepaald motief. In het Nederlandse strafrecht zijn delictsomschrijvingen echter vooral afgestemd op de psychische gesteldheid van de dader (opzettelijk handelen); motieven spelen op het niveau van de strafbaarstelling nauwelijks een rol. Ten tweede zou de specifieke voorziening erin bestaan dat het eerwraakmotief strafverzwarend werkt. ${ }^{18}$ Het gaat dus niet alleen om het verhelderen van de normstelling. Hoewel er in de Tweede Kamer meermalen over is gediscussieerd, is het aanmerken van het eerwraakmotief als een wettelijke strafverzwarende omstandigheid steeds afgewezen. Het zou niet nodig zijn omdat het feit dat een moord uit eerwraak is begaan, gewoon een omstandigheid is waarmee de rechter rekening kan houden bij het bepalen van de hoogte van de straf. ${ }^{\mathrm{I} 9}$ Wenselijk is het volgens de minister van justitie ook niet. Een moord begaan uit winstbejag zou minstens zo verwerpelijk zijn als een eergerelateerde moord. Daarnaast zou sprake zijn van symboolwetgeving omdat het motief moeilijk te bewijzen valt en de praktijk er dus geen gebruik van zal maken. Het Wetboek van Strafrecht is er echter niet, aldus de minister, om politieke signalen af te geven. ${ }^{20}$

\section{Kindermishandeling}

Tot voor kort kon de als mishandeling te kwalificeren 'opvoedende klap' worden gerechtvaardigd op grond van het ouderlijk tuchtigingsrecht. Sinds vorig jaar is daarvoor geen ruimte meer. Aan het tweede lid van art. 247 van Boek I van het BW is de volgende zin toegevoegd: 'In de verzorging en opvoeding van het kind passen de ouders geen geestelijk of lichamelijk geweld of enige andere vernederende behandeling toe. ${ }^{2 \mathrm{I}}$ Hoewel kindermishandeling op zichzelf natuurlijk geen specifiek cultureel delict is, zou de wetswijziging mede een culturele achtergrond hebben, in die zin dat dit fenomeen zich met name in de opvoedingspraktijken van bepaalde culturele minderheidsgroeperingen zou voordoen. De wetswijziging is dan een signaal in de richting van die groeperingen dat geweld jegens kinderen in het kader van de opvoeding onaanvaardbaar is. ${ }^{22}$

I7. Zie hierover Ten Voorde, Cultuur als verweer, a.w., p. 40.

I8. Op moord staat al de maximale tijdelijke gevangenisstraf en zou het motief dus niet strafverzwarend kunnen werken, tenzij ook op dit punt de wet wordt aangepast.

19. Aanhangsel Handelingen II 2003-2004, nr. 301.

20. Kamerstukken II 28345 , nr. 40 , p. II.

2I. Stb. $2007, \mathrm{I} 45$.

22. Vgl. Schuyt, a.w., p. Iоo. 
Verbod van geloofsdwang?

Volgens art. 284 onder $\mathrm{I}^{\mathrm{O}} \mathrm{Sr}$ is strafbaar: 'hij die een ander door geweld of een andere feitelijkheid of door dreiging met geweld of enige andere feitelijkheid, gericht hetzij tegen die ander hetzij tegen derden, wederrechtelijk dwingt iets te doen, niet te doen of te dulden'. Tweede Kamerlid Halsema (Groen Links) heeft voorgesteld om geloofs- of gewetensdwang expliciet te verbieden, door in art. $284 \mathrm{Sr}$ tevens strafbaar te stellen: 'hij die een ander dwingt om godsdienstige, levensbeschouwelijke of ideologische opvattingen te belijden'. Dit verbod, dat ook al vervat is in de algemene dwangbepaling (onder $\mathrm{I}^{\circ}$ ), zou van belang zijn 'om de gewetensvrijheid van burgers beter te beschermen, bijvoorbeeld voor sekteleden die willen uittreden. Geloofsdwang leidt verder ook tot de problemen die ex-moslims in hun gemeenschappen ondervinden.'23 De minister heeft toegezegd de noodzaak van zo'n wijziging te onderzoeken.

\section{Boerkaverbod?}

Het veel bediscussieerde boerkaverbod neemt een wat bijzondere plaats in. Er bestaan in het Nederlandse recht diverse mogelijkheden om het dragen van gelaatsbedekkende kleding te verbieden. Gelaatsbedekkende kleding kan verboden zijn - bijvoorbeeld op basis van een algemene plaatselijke verordening - in verband met de handhaving van de openbare orde en de veiligheid of de uitoefening van bepaalde functies. ${ }^{24}$ Hoewel het waarschijnlijk geen wet zal worden, is voor ons onderwerp eigenlijk vooral het vorig jaar door Tweede Kamerleden Wilders en Fritsma (Partij voor de vrijheid (!)) ingediende wetsvoorstel interessant. Een nieuw art. 442b Sr zou moeten luiden: 'Degene die op een openbare plaats een boerka of een nikaab draagt, wordt gestraft met hechtenis van ten hoogste twaalf dagen of geldboete van de tweede categorie. ${ }^{25}$ Het gaat hier dus niet om gelaatsbedekkende kleding in het algemeen, maar om speciefiek een boerka of een nikaab. Bovendien is het verbod niet beperkt tot het dragen van een boerka in bepaalde functies of in bepaalde situaties, maar 'op een openbare plaats'. Dit verbod creëert een cultureel delict bij uitstek, zoals schaking dat ook is; feitelijk wordt het alleen begaan door mensen met een niet-Nederlandse culturele achtergrond. In de toelichting op het voorstel wordt de veiligheid wel als een argument voor de strafbaarstelling genoemd, maar niet als eerste (als het primair om de veiligheid gaat, ligt het ook niet voor de hand alleen de boerka te verbieden). Het eerste 'kernargument' wordt als volgt geformuleerd:

'De boerka of de nikaab staat haaks op de moderniteit. Het is een uiting van afwijzing van de Westerse kernwaarden en kernnormen, waaronder de gelijkwaardigheid van mannen en vrouwen. De boerka of de nikaab is deswege een symbool van vrouwenonderdrukking, ongeacht of de boerka of de nikaab gedwongen dan wel vrijwillig gedragen wordt. Nu de boerka of de nikaab symboliseert dat aan vrouwen een onderge-

23. Kamerstukken II 2007-2008, 3I 200 VI, nr. I30 p. 3.

24. Zie hierover de brief van de ministers van Binnenlandse Zaken en Koninkrijksrelaties, van Justitie, voor Wonen, Wijken en Integratie en van Onderwijs, Cultuur en Wetenschap, Kamerstukken II 20072008, 3I200 VII, nr. 48.

25. Kamerstukken II 2006-2007, 3II08, nr. I-2. 
schikte rol ten opzichte van mannen is toebedeeld, is de boerka of de nikaab volstrekt onverenigbaar met de Westerse fundamentele rechtsstatelijke waarden. Het dragen van een boerka of een nikaab in de openbare ruimte is aldus in strijd met de democratische rechtsstaat. ${ }^{26}$

Overheidsbemoeienis met het dragen van een boerka geheel los van overwegingen van openbare orde, veiligheidsoverwegingen of beroepseisen, is echter in een democratische rechtsstaat, waarin de burger de vrijheid heeft zo veel mogelijk zijn leven te leiden zoals hij dat zelf wil, juist niet vanzelfsprekend (ook afgezien van godsdienstvrijheid). ${ }^{27}$ Zoals de toelichting zelf stelt: het dragen van een boerka 'symboliseert' iets dat in strijd is met de democratische rechtsstaat (althans in veel gevallen). Maar symbolen zijn niet hetzelfde als datgene wat zij symboliseren. ${ }^{28}$

\section{Rekening houden met andere culturen}

Voorbeelden van wetgeving waarin expliciet ruimte wordt gelaten aan culturele gewoonten en gebruiken van minderheden liggen op het vlak van het (mede) strafrechtelijk gesanctioneerde bestuursrecht. De wetgever wil dan wel niets weten van rechtspluralisme (par. 3), dat wil niet zeggen dat binnen het (ene) Nederlandse rechtssysteem geen rekening kan worden gehouden met andere culturen. De Nederlandse staat heeft als uitgangspunt

'dat iedereen die in Nederland verblijft zoveel mogelijk in staat gesteld moet worden om zijn of haar leven naar eigen inzicht in te richten. (...) Daarom streeft het kabinet ernaar om in wet- en regelgeving ruimte te bieden voor gebruiken die weliswaar niet tot het nationale erfgoed behoren, maar die op zich niet strijdig zijn met basale uitgangspunten. ${ }^{29}$

Bekende voorbeelden zijn bijzondere wijzen van lijkbezorging en slachten. ${ }^{30}$ De Wet op de lijkbezorging ${ }^{3 \mathrm{I}}$ en het daarop gebaseerde Besluit ${ }^{32}$ bieden volop ruimte voor afwijkende begrafenisrituelen, in het bijzonder voor lijkbezorging overeenkomstig islamitische tradities. Zo is begraven (en verbranden) zonder kist toegestaan, mits het lijk zich in een omhulsel bevindt dat is afgestemd op het doel van de begraving. ${ }^{33}$ Ook het ritueel slachten is door de wetgever erkend. De Gezondheids- en welzijnswet staat het slachten van dieren zonder voorafgaande bedwelming volgens de israëlitische of islamitische ritus toe (art. 44 lid 3 ). ${ }^{34}$

\footnotetext{
26. Kamerstukken II 2006-2007, 31108, nr. 3, p. 2.

27. Indien de vrouw gedwongen wordt een boerka te dragen, liggen de zaken geheel anders. Dat is al zonder meer strafbaar als 'dwang', art. $284 \mathrm{Sr}$.

28. Waarmee natuurlijk niet is gezegd dat symbolen geen voorwerp van een strafrechtelijk verbod kunnen zijn (denk aan belediging of discriminatoire uitlatingen).

29. Kamerstukken II 2006-2007, 30800 VI, nr. II5, p. 24.

30. Uitgebreid hierover H. Wiersinga, Het 'beschavingsoffensief' en de wetgever. Over culturele factoren in wetgeving, Recht en kritiek I997, p. I50.

3I. Stb. I99I, I33.

32. Besluit op de lijkbezorging, Stb. I99I, 252.

33. Art. 3 lid 2 en art. 8 Besluit op de lijkbezorging.

34. Stb. 1992, 585. Voor nadere voorschriften zie het Besluit ritueel slachten, Stb. I996, 573.
} 


\subsection{Bepalingen aangaande de vervolgbaarheid}

Bestaat voor meisjesbesnijdenis geen aparte strafbaarstelling, wat betreft de vervolgbaarheid gelden wel bijzonderheden. Sinds kort is er een rechtsmachtsbepaling waarin naar dit culturele delict verwezen wordt. Op grond van art. 5 lid I aanhef en onder $3^{\circ} \mathrm{Sr}$ is de Nederlandse strafwet toepasselijk op de Nederlander die zich buiten Nederland schuldig maakt aan (zware) mishandeling 'voor zover het feit oplevert genitale verminking van een persoon van het vrouwelijke geslacht die de leeftijd van achttien jaren nog niet heeft bereikt'. ${ }^{35}$ Hetzelfde geldt voor de vreemdeling die in Nederland een vaste woon- of verblijfplaats heeft (art. 5a lid I Sr). Dit is een toepassing van het onbeperkt personaliteitsbeginsel. Onbeperkt: de strafwet is ook toepasselijk indien besnijdenis niet strafbaar is naar het recht van de staat waar het feit is begaan. Het onbeperkt personaliteitsbeginsel geldt van oudsher voor een aantal feiten die geacht worden dusdanig grote Nederlandse belangen te raken dat een Nederlander - uit loyaliteit aan de Nederlandse staat - ze overal heeft te eerbiedigen (onder meer misdrijven tegen de veiligheid van de staat, maar ook bigamie). Het onbeperkt personaliteitsbeginsel heeft in de loop der jaren echter nog een andere functie gekregen en de rechtsmachtsuitbreiding voor besnijdenis past in deze trend. De minister van justitie zei daarover:

'Overheersende gedachte in Nederland is dan dat Nederlanders normen wier naleving voor onze rechtsorde van groot belang zijn, zoals normen die strekken tot bescherming van de menselijke waardigheid, niet alleen in Nederland, maar ook daarbuiten dienen te respecteren.'

Het gaat hier om delicten die in de meeste landen strafbaar zijn gesteld. De omstandigheid dat dit in sommige landen niet zo is, kan voor Nederlanders aanleiding zijn juist naar die landen te gaan om daar de feiten te begaan. Die Nederlanders maken in dat geval 'vanuit de Nederlandse optiek (...) misbruik van lacunes in de strafwetgeving van die landen'.${ }^{6}$ Opmerkelijk is dat vervolging zelfs kan plaatshebben als de van besnijdenis verdachte persoon pas ná het begaan van het feit Nederlander wordt (art. 5 lid $2 \mathrm{Sr}$ ) dan wel een vaste woon- of verblijfplaats in Nederland heeft gekregen (art. 5 a lid 2 Sr). ${ }^{37}$ De minister erkent dat het legaliteitsbeginsel hier in het gedrang kan komen. De verdachte moet kunnen weten dat hij in Nederland vervolgd kan worden. ${ }^{38}$ De minister wijst er in dit verband op dat het verwerven van het Nederlanderschap dan wel het verkrijgen van een vaste woon- of verblijfplaats doorgaans het gevolg is van een persoonlijke keuze:

35. Stb. 2006, II.

36. Kamerstukken II 2003-2004, 2945I, nr. I, p. I4.

37. Dit geldt ook voor de in art. 5 lid $\mathrm{I}$ sub $2^{\mathrm{O}}$ en voor alle in art. $5 \mathrm{a}$ lid I Sr genoemde delicten.

38. Dit is al een 'oprekking' van het legaliteitsbeginsel. De burger hoeft niet vóór het verrichten van de gedraging te kunnen weten of die gedraging tot vervolging in Nederland zou kunnen leiden. Voldoende is al dat de verdachte, dus nadat hij de gedraging zou hebben verricht, kan weten dat zijn gedraging tot vervolging in Nederland kan leiden. 
'Er is dus wetenschap vooraf, of die kan er zijn, dat het aanknopen van banden met de Nederlandse rechtsorde met zich kan brengen dat een vervolging wordt ingesteld terzake van strafbare feiten die in Nederland als zeer ernstig worden aangemerkt, waaronder meisjesbesnijdenis. 39

Waar van een vrije keuze geen sprake is, zou, afhankelijk van de omstandigheden, het vervolgingsrecht kunnen ontbreken.

Verder is een wetsvoorstel aanhangig dat de verjaring van het recht tot strafvervolging voor meisjesbesnijdenis verruimt. ${ }^{\circ}$ Hoofdregel is dat de verjaring begint te lopen vanaf de dag nadat het feit is gepleegd (art. 7I aanhef Sr). Deze regel kent enkele uitzonderingen. Een daarvan is dat voor gevallen van seksueel misbruik van kinderen de verjaringstermijn pas gaat lopen als het minderjarige slachtoffer meerderjarig wordt (art. $7 \mathrm{I}$ onder $3^{\circ} \mathrm{Sr}$ ). Voorgesteld wordt om deze uitzondering ook toe te passen op meisjesbesnijdenis. Aldus wordt de kans op aangifte vergroot, omdat het slachtoffer meer tijd krijgt om als volwassene na te denken over de besnijdenis en zich bewust te worden van de mogelijkheid van aangifte, haar wensen daaromtrent en de gevolgen daarvan.

\subsection{Van algemene regel naar toepassing (vooruitblik)}

Cultuur is weinig zichtbaar in de Nederlandse (straf)wet. Dit gegeven betekent dat men bij de vraag hoe cultuur doorwerkt in het Nederlandse strafrecht met een enorm 'onderzoeksveld' te maken heeft. Alleen de eerder genoemde feitelijk culturele delicten als schaking vallen erbuiten. Die delicten zijn immers in die zin niet meer interessant, dat de strafbaarheid daarvan al vaststaat, althans op bestanddeelniveau. Bij alle andere strafbepalingen kan - in elk geval in theorie - de vraag gesteld worden hoe cultuur door kan werken bij de interpretatie van de delictsbestanddelen. Hetzelfde geldt voor de strafuitsluitingsgronden. Er is wel weer een kleine beperking, namelijk voor zover de wetgever voor bepaalde culturele fenomenen een aparte regeling heeft ontworpen, zoals in de Wet op de lijkbezorging, waarmee die gedragingen juist expliciet worden uitgesloten van strafbaarheid.

Hierna zal worden bezien hoe culturele normen en meer in het algemeen culturele gegevens een rol kunnen spelen bij de toepassing van de strafwet, dus bij de beoordeling van de strafbaarheid van feit en dader in concrete gevallen. Dit gebeurt aan de hand van de beslissingsstructuur ex art. 350 Sv. De rechter dient zich, na afloop van het onderzoek ter terechtzitting, eerst te buigen over de vraag of het ten laste gelegde feit bewezen kan worden; zo ja, dan dient hij te beoordelen of er een toepasselijke en verbindende strafbepaling is volgens welke het bewezenverklaarde feit als een strafbaar feit is te kwalificeren; indien ook dat het geval is, is de vraag of de dader strafbaar is: zijn er wellicht strafuitsluitingsgronden?; ten slotte dient de rechter zich uit te spreken over de op te leggen sanctie. Aan de hand van deze vragen en in deze volg-

39. Kamerstukken I 2004-2005, 28484, D, p. 2.

40. Kamerstukken II 2007-2008, 31386, nr. I e.v. 
orde ${ }^{4 \mathrm{I}}$ wordt, mede aan de hand van de rechtspraak, in het onderstaande de rol van cultuur bezien. Gelet op het zojuist opgemerkte over het enorme 'onderzoeksveld' wordt niet getracht een compleet beeld te schetsen.

In deze aanpak is de door de officier van justitie te nemen vervolgingsbeslissing geen item; die beslissing is dan al lang genomen. Toch is een korte opmerking daarover op zijn plaats. Of vervolgd zal worden hangt allereerst af van de haalbaarheid van een veroordeling. Indien de officier van justitie van mening is dat een veroordeling door de rechter niet waarschijnlijk is, zal hij niet vervolgen. Dat aspect heeft hier geen zelfstandige relevantie, in die zin dat het openbaar ministerie op dit punt anticipeert op het oordeel van de rechter en zich dus voor dezelfde vragen gesteld ziet als de rechter. Naast haalbaar moet vervolging ook gewenst zijn: het opportuniteitsbeginsel. De officier van justitie kan van (verdere) vervolging afzien op gronden aan het algemeen belang ontleend (art. I 67 lid 2 en 242 lid 2 Sv). Het opportuniteitsbeginsel geeft aan het Nederlandse strafrecht een grote flexibiliteit. ' $t$ Hart heeft die flexibiliteit benadrukt, juist ook in verband met culturele delicten:

'Een flexibel strafrechtelijk optreden kan zowel individuele gevallen moeten betreffen (bijvoorbeeld wanneer er in wettelijke regelingen of feitelijke constellaties nog onvoldoende rekening is gehouden met problemen van etnische minderheden en religieuze groeperingen, zoals wanneer dochters van orthodoxe moslims ingevolge de Leerplichtwet op school moeten deelnemen aan gemengde zwemlessen) als bepaalde groepen, bijvoorbeeld wanneer bepaalde groepen etnische minderheden speciale problemen opleveren.' 42

Deze, voor de praktijk zeer belangrijke opportuniteitsvraag blijft verder buiten beschouwing.

\section{$5 \quad$ Gebruik van culturele gegevens bij het bewijs}

Culturele factoren kunnen een rol spelen bij 'puur feitelijke' bewijskwesties. Dit kan zich bij tal van bestanddelen voordoen. Een aantal voorbeelden ter illustratie.

\section{Voorbedachte raad}

Moord is doodslag begaan met voorbedachte raad (art. $289 \mathrm{Sr}$ ). De voorbedachte raad fungeert als een strafverzwarende omstandigheid. ${ }^{43}$ De dader heeft de ander niet in een ogenblikkelijke gemoedsopwelling opzettelijk gedood, maar hij heeft erover nagedacht, of de gelegenheid gehad erover na te denken. In veel eerwraak-

4I. Opgemerkt zij dat in de praktijk kwalificatievragen doorgaans al bij de bewijsvraag aan de orde komen. In de tenlastelegging wordt het feit namelijk vaak omschreven met gebruikmaking van de delictsbestanddelen. Het bestanddeel moet dan in zijn juridische betekenis bewezen kunnen worden.

42. A.C. 't Hart, Recht en pluralisme, in: Daar gelden wetten!, Deventer: Gouda Quint 200I, p. 2Io.

43. Ook bij bijvoorbeeld (zware) mishandeling, zie art. zor (en 303) Sr. 
zaken speelt de vraag naar de aanwezigheid van voorbedachte raad. HR I5 april I986, NJ I986, 74I betrof een Turk die, ter vervulling van een jarenlang sluimerend gehouden eerwraak, op een bruiloft een landgenoot doodschiet. Is het meenemen van het pistool naar de bruiloft een aanwijzing dat de man met voorbedachte raad heeft gedood? Volgens de raadsman niet: in de Turkse cultuur gaat een man niet zonder pistool naar een bruiloft, want juist bij die gelegenheden zou het als symbool van mannelijkheid niet gemist kunnen worden. In een andere zaak, over een man die zijn broer heeft gedood vanwege het feit dat deze een jarenlange relatie met de echtgenote van verdachte heeft gehad, gebruikt de Rechtbank Leeuwarden een cultureel gegeven ter ondersteuning van het bewijs van voorbedachte raad. ${ }^{44}$ Behalve de wijze waarop de verdachte het slachtoffer heeft gedood, wijst ook het gedrag daarna erop dat het doden niet in een gemoedsopwelling heeft plaatsgevonden: 'Immers nadat verdachte de dood had geconstateerd heeft hij volgens de gebruiken van zijn geloof een gebed uitgesproken, een kleedje onder het hoofd gelegd en het slachtoffer afgedekt.' Duidelijke gevallen van moord zijn ook die, waarbij vooraf familieberaad heeft plaatsgevonden. Er is dan sprake van een ruim van tevoren genomen besluit de ander te doden, gevolgd door een planmatig handelen. ${ }^{45}$ Maar eerwraak als motief voor de levensberoving impliceert op zichzelf nog geen voorbedachte raad. De dader die onverwachts wordt geconfronteerd met een eerkrenkende situatie kan in een plotselinge opwelling de ander doden of mishandelen. ${ }^{46}$

\section{Medeplegen}

De deelnemingsvorm medeplegen vereist 'bewuste en nauwe samenwerking'. Een gewelddadige confrontatie tussen twee Koerdische families was de laatste gebeurtenis in de bloedwraak tussen de families. Naast allerlei andere redengevende feiten, was er volgens het Hof Arnhem 'mede gelet op de bestaande bloedvete' sprake van medeplegen. ${ }^{47}$ De bloedvete vormde voor de rechter kennelijk een aanwijzing voor de bewuste en nauwe samenwerking. Verder kan voor het bewijs van medeplegen relevant zijn dat voorafgaand familieberaad heeft plaatsgehad (vergelijk de voorbedachte raad). Dat wil echter niet zeggen dat iedere deelnemer aan het beraad reeds daarom medepleger is. Uiteindelijk is beslissend of iemands rol van voldoende gewicht is om hem als medepleger aan te merken (en niet bijvoorbeeld als medeplichtige). ${ }^{48}$

\section{Opzet, oogmerk}

Het Nederlandse opzet-bestanddeel is 'kleurloos': opzet op de daad is voldoende, vereist is niet dat de dader weet heeft van het wederrechtelijke ervan. Het verweer van de culturele dader dat hij niet wist dat hij in strijd met het recht handelde, is dus irrelevant (tenzij hij daaromtrent verontschuldigbaar dwaalde, zie par. 7.5). Toch kunnen culturele factoren een rol spelen bij het bewijs van subjectieve bestanddelen

44. Rechtbank Leeuwarden 3 mei 2005, LJN: AT4973.

45. Zie bijvoorbeeld Rechtbank's-Gravenhage 25 februari 2002, LJN: AD9567.

46. Zie bijvoorbeeld Rechtbank Alkmaar 4 maart 2008, LJN: BC5712.

47. Hof Arnhem I2 juni 2002, LJN: AE4024.

48. Zie bijvoorbeeld Rechtbank Dordrecht 24 juni 2004, LJN: AP440I. 
als opzet en oogmerk. Voor feitelijke aanranding van de eerbaarheid (art. $246 \mathrm{Sr}$ ) is vereist dat de dader opzet heeft (besloten in het 'dwingen') op het tegen de wil van het slachtoffer doen ondergaan van ontuchtige handelingen. Het is denkbaar dat iemand, vanwege zijn culturele achtergrond, niet doorheeft (zelfs niet de aanmerkelijke kans aanvaardt, voorwaardelijk opzet), dat het slachtoffer tegen haar wil de handelingen ondergaat, al zal de rechter daar niet snel aan willen. ${ }^{49}$

De pleger van schaking (art. 28I Sr) voert de vrouw weg 'met het oogmerk om zich haar bezit in of buiten echt te verzekeren'. Bedoeld is dat de dader gehandeld moet hebben met als naaste doel om met de vrouw seksuele gemeenschap te hebben. Volgens Mulder hoeft niemand 'te twijfelen aan het oogmerk van bezit in echt, wanneer volgens het Islamitisch recht of het huwelijksrecht van de Syrisch-orthodoxe kerk het huwelijk pas geconsumeerd zou zijn door geslachtsgemeenschap'. ${ }^{\circ}$ Daarmee lijkt hij over het hoofd te zien dat in de praktijk schakingen ook voorkomen om een verblijfstitel te verkrijgen en alleen om die reden een huwelijk wordt gesloten. ${ }^{{ }^{\mathrm{I}}}$ Cultureel bepaalde denkbeelden kunnen het bewijs van het oogmerk ook juist in de weg staan. Zo ontbreekt bij iemand het voor oplichting vereiste bedrieglijke oogmerk (art. $326 \mathrm{Sr}^{52}$ ), indien die persoon zelf van de juistheid van zijn praktijken, die voor anderen wellicht zeer dubieus zijn, overtuigd is. Dit deed zich voor bij de zogenaamde brua-genezers ('brua' is de aanduiding voor zwarte magie op de Nederlandse Antillen). 53

\section{Toestemming}

Toestemming is bij een aantal delicten bestanddeel (soms impliciet). Het eerdergenoemde schakingsdelict kent twee varianten: het wegvoeren van de minderjarige vrouw mét haar toestemming, maar 'zonder de wil van haar ouders of voogden' (art. 28I onder $\mathrm{I}^{\mathrm{O}} \mathrm{Sr}$ ) en het door list, geweld of bedreiging met geweld een vrouw wegvoeren (onder $2^{\circ}$ ), wat impliceert dat het wegvoeren tégen de wil van de vrouw geschiedt. Bij beide varianten kunnen culturele factoren het bewijs bemoeilijken. ${ }^{54}$ De vrouw kan, in strijd met de waarheid, beweren geen toestemming te hebben gegeven omdat ze bang is problemen te krijgen met haar familie. Maar ook kan ze beweren juist wel met de gang van zaken te hebben ingestemd omdat ze bang is geen andere man meer te kunnen krijgen.

\section{Witwassen}

Culturele factoren kunnen bij de meest uiteenlopende delicten een rol spelen. In Rechtbank 's-Gravenhage 9 maart 2007, LJN: BA037I ging het om witwassen van

\footnotetext{
49. Vgl. Rechtbank's-Hertogenbosch i9 maart 2008, LJN: BC7030.

50. Zie G.E. Mulder onder HR 2 juli I990, NJ I99I, IIo.

5I. Zie A.L.J. van Strien en H. van Maurik, Strafrecht. Tekst \& Commentaar Strafrecht, Deventer: Kluwer 2006, aant. 8 bij art. 28r.

52. Art. $326 \mathrm{Sr}$ : Hij die, met het oogmerk om zich of een ander wederrechtelijk te bevoordelen, hetzij door het aannemen van een valse naam of van een valse hoedanigheid, hetzij door listige kunstgrepen, hetzij door een samenweefsel van verdichtsels, iemand beweegt tot de afgifte van enig goed.

53. Zie bijvoorbeeld HR 26 november i968, NJ i969, 36r. Vgl. J. Remmelink, De overtuigingsdader, in: Honderd jaar rechtsleven, De Nederlandse Juristen Vereniging I870-1970, Zwolle 1970, p. I83.

54. Zie hierover A. Nellestein, Achtergronden van Turkse ontvoeringszaken, Algemeen Politieblad I98I, p. 5 I e.v.
} 
gelden (art. 42obis Sr). ${ }^{55}$ De verdachten hadden geldsbedragen naar het buitenland overgemaakt. Volgens de officier van justitie kon het niet anders of deze bedragen waren van misdrijf (drugshandel) afkomstig. De verdachten verklaarden daarentegen dat de bedragen het resultaat waren van hard werken in de prostitutie, niet door henzelf, maar door mensen in hun omgeving. Zij, de verdachten, werden op straat aangesproken met het verzoek geld over te maken. Omdat het in de Dominicaanse cultuur niet ongebruikelijk is aan een dergelijk verzoek gevolg te geven, zeker daar de personen in kwestie in verband met hun drukke werkzaamheden geen tijd hadden zelf geld over te maken, hadden zij dit op zich genomen. Die verklaring kwam de rechtbank niet op voorhand onaannemelijk voor (en uiteindelijk volgde, mede op andere gronden, vrijspraak).

Het gebruik van culturele gegevens zoals in de hierboven beschreven gevallen gebeurt, is op zichzelf onproblematisch. De betekenis van de strafrechtelijke norm staat niet ter discussie. Toch dient de rechter voorzichtig te zijn met dit gebruik. Is het wel een cultureel gegeven? Geldt dat ook in deze zaak? Heeft de verdachte werkelijk vanuit zijn cultuur gehandeld of verschuilt hij zich daarachter? Ook bestaat het gevaar van gemakzuchtigheid bij het trekken van conclusies uit culturele gegevens. Een eerwraakmotief duidt op zichzelf nog niet op voorbedachte raad. Deelneming aan een familieberaad voorafgaand aan het delict maakt iemand nog niet zonder meer tot medepleger aan het delict..$^{6}$

\section{Cultuur en interpretatie van delictsbestanddelen}

Culturele factoren kunnen niet alleen relevant zijn voor het bewijs; zij kunnen ook de juridische betekenis van bestanddelen ter discussie stellen. Ook dat zal met een aantal voorbeelden toegelicht worden.

\section{Voorbedachte raad}

In een van de eerste eerwraakzaken waarover de Hoge Raad zich moest buigen ging het om de betekenis van voorbedachte raad. ${ }^{57} \mathrm{Na}$ veroordeling wegens moord door het hof, werd in cassatie betoogd dat

'indien er al sprake was van enig plan of voornemen jegens het slachtoffer T., zulks naar alle waarschijnlijkheid het resultaat is van: a. aansporing c.q. aanmoediging of aanzetting in enigerlei vorm door de heer B. en/of diens familie, vanwege de bestaande bloedvete tussen deze en het slachtoffer; b. een gezamenlijk verlangen van de familie van req., althans van enige mannelijke familieleden, om genoegdoening te verkrijgen

55. Art. 42obis lid I: hij die een voorwerp (daaronder vallen ook vermogensrechten, zie lid 2) verwerft, voorhanden heeft, overdraagt of omzet of van een voorwerp gebruik maakt, terwijl hij weet dat het voorwerp - onmiddellijk of middellijk - afkomstig is uit enig misdrijf.

56. Uit het onderzoek van Siesling (a.w., p. I57) blijkt dat advocaten juist daarom soms huiverig zijn om de culturele achtergond in te brengen.

57. HR I februari $1977, \mathrm{NJ}$ I977, 563. 
voor de geschonden eer van de familie. (...) Van voorbedachte raad, die geheel zou zijn toe te schrijuen aan req. [curs. HDW], kan dan geen sprake zijn.'

Het is niet geheel duidelijk wat het middel met dit laatste bedoelt. De gedachtegang van het middel volgend, zou uitlokking van moord überhaupt niet mogelijk zijn, omdat de voorbedachte raad steeds ook aan de uitlokker zou zijn toe te schrijven. De Hoge Raad gaat er in ieder geval niet in mee en stelt eenvoudig dat 'indien req.s plan of voornemen het resultaat mocht zijn geweest van de (...) onder a. en b. omschreven factoren (...) zulks niet aan 's Hofs voormelde oordeel en gevolgtrekking in de weg zou staan'.

Volgens de Hoge Raad in recente arresten is voor voorbedachte raad voldoende dat verdachte tijd had zich te beraden op het te nemen of het genomen besluit, zodat de gelegenheid heeft bestaan dat hij over de betekenis en de gevolgen van zijn voorgenomen daad heeft nagedacht en zich daarvan rekenschap heeft gegeven. ${ }^{8}$ Aldus worden geen hoge eisen gesteld. Toch betwijfelt Wiersinga ${ }^{59}$ of bij eerwraak waaraan familieberaad vooraf is gegaan, zelfs aan deze sobere omschrijving wel steeds is voldaan. In de omschrijving zou besloten liggen dat de dader zich nog moet hebben kunnen bedenken wil van voorbedachte raad sprake zijn. Zij vraagt zich af, enigszins in het verlengde van het zojuist besproken cassatiemiddel, of de dader van 'de typische eerwraak, waarbij het niet zozeer om een individueel besluit gaat', zich nog wel kan bedenken. Het 'vonnis' wordt weliswaar koelbloedig uitgevoerd, maar die koelbloedigheid is er een 'van een loyale uitvoerder die een als het ware bovenpersoonlijk bevel opvolgt en een daad pleegt die noodzakelijk en onvermijdelijk is'. Wellicht is het onder omstandigheden voor de dader onmogelijk om zich nog te bedenken. Of dat ertoe leidt dat het bestanddeel voorbedachte raad niet is vervuld, is dan echter nog de vraag. Is men daarmee niet in de sfeer van de strafuitsluitingsgronden beland (psychische overmacht)? En als de dader zich niet heeft kúnnen bedenken, zou hij dan niet geheel vrijuit moeten gaan, dus niet alleen voor moord, maar ook voor doodslag?

Korte vergelijking met 'Mordmerkmale' naar Duits recht

Als gezegd, de Hoge Raad omschrijft de voorbedachte raad sober. Het bestanddeel heeft een 'vlakke', ethisch-neutrale betekenis. Motieven spelen geen rol. Het Duitse strafrecht kent 'Mordmerkmale' die veel minder neutraal zijn. Moord is het doden van een ander uit - onder meer - 'Mordlust, zur Befriedigung des Geschlechtstriebs, aus Habgier oder sonst aus niedrigen Beweggründen' (§ 2II StGB). Het zijn vooral de 'niedrige Beweggründe' die in de Duitse rechtspraak over eer- en bloedwraakgevallen centraal staan. Een motief is 'laag' wanneer het dodingsmotief 'nach allgemeiner sittlicher Würdigung auf tiefster Stuhe steht und deshalb besonders verachtenswert ist'. ${ }^{\circ}$ Voor de vraag of de dader met een laag motief heeft gehan-

58. Zie o.m. HR 27 juni 2000, NJ 2000, 605 .

59. H. Wiersinga, Gevallen van eerwraak in Nederland en het beslissingsmodel van de strafrechter, in: Ontmoetingen, Voordrachtenreeks van het Lutje P.J.G., 200I, nr. 7, p. I4.

6o. Vaste rechtspraak; zie hierover A. Eser in A. Schönke en H. Schröder, Strafgesetzbuch, Kommentar, München: Beck 2006, § 2II, anm. I9. 
deld, is de cultuur van de dader in zoverre irrelevant, dat het motief beoordeeld moet worden aan de hand van de 'Vorstellungen der Rechtsgemeinschaft in der Bundesrepublik Deutschland (...), und nicht den Anschauungen einer Volksgruppe, die die sittlichen und rechtlichen Werte dieser Rechtsgemeinschaft nicht anerkennt'. ${ }^{6 \mathrm{I}} \mathrm{De}$ dader hoeft ook niet zélf zijn motief als laag in te schatten; voldoende is dat hij zich bewust is van de (objectieve) omstandigheden die maken dat het om een laag motief gaat, maar die kennis zal bij de eerwraakdader doorgaans aanwezig zijn. Het eerwraakmotief is in de regel dan ook laag, maar er zijn uitzonderingen:

'Wurde der einem fremden Kulturkreis - der Blutrache duldet oder gar fordert - entstammende Täter noch derart stark von den Vorstellungen und Anschauungen seiner Heimat beherrscht, dass er sich von ihnen zur Tatzeit aufgrund seiner Persönlichkeit und der gesamten Lebensumstände nicht lösen konnte, dann kann ausnahmsweise auch bei einer Tötung aus Blutrache eine Verurteilung lediglich wegen Totschlags in Betracht kommen. ${ }^{62}$

In een dergelijk uitzonderlijk geval is het de dader niet te verwijten dat hij 'aus niedrigen Beweggründen' gedood heeft en kan geen veroordeling voor moord volgen. Veroordeling voor doodslag blijft mogelijk. De dader heeft wel een ander opzettelijk van het leven beroofd en het ontbreken van de 'niedrige Beweggründe' doet aan de verwijtbaarheid van die opzettelijke levensberoving niet af.

Lijkt de culturele achtergrond in het Nederlandse strafrecht weinig invloed te kunnen hebben op de afwezigheid van een kwalificerende (strafverhogende) omstandigheid als voorbedachte raad, er zijn ook geen wettelijke strafverlagende omstandigheden waar die achtergrond zijn invloed kan doen gelden. Het Nederlandse strafrecht kent bijvoorbeeld niet de voor de culturele dader mogelijk relevante 'provocatie' als strafverminderingsgrond. Ook hier laat het Duitse recht een ander beeld zien. Duitsland kent de 'provozierte Totschlag' (\$ 2I3 StGB): is de pleger van een doodslag buiten zijn schuld door een mishandeling of zware belediging van de zijde van het slachtoffer 'zum Zorne gereizt und hierdurch auf der Stelle zur Tat hingerissen worden', dan geldt een minder zware strafbedreiging. Bij culturele daders speelt deze bepaling nog wel eens een rol.

\section{Medeplegen}

Wat betreft het medeplegen en de mogelijke culturele invloed op het handelen van de dader kan gewezen worden op een vrij recente zaak over een erekwestie binnen het milieu van Iranese moslims. ${ }^{6} 3$ De ouders van het slachtoffer, een I6-jarig meisje, kwamen erachter dat hun dochter door haar vriend ontmaagd was. Daarmee was de familie-eer geschonden, die alleen weer 'bedekt' zou worden wanneer het meisje

6I. Zie bijvoorbeeld BGH StV I996, 208; BGH NStZ 2002, 369; BGH NStZ 2004, 332. Zie hierover vooral Kay Nehm, Blutrache - ein niedriger Beweggrund?, in: Menschengerechtes Strafrecht (Festschrift für Albin Eser), Verlag C.H. Beck München 2005, p. 4I9 e.v.

62. BGH 7 oktober I994, NJW I995, p. 602, 603.

63. Hoge Raad I4 oktober 2003, NJ 2005, I83. 
zou trouwen met de vriend. De vriend weigerde dat. Herstel van de familie-eer was nu alleen nog mogelijk door de dochter te doden. De vader voerde de moord uit. De moeder werd vervolgd wegens het medeplegen daarvan. De rechter baseerde het bewijs van medeplegen niet alleen op de wetenschap van het voorgenomen plan en de handelingen die de moeder had verricht, maar ook op het feit dat zij 'vanaf de dreigende verwerkelijking van de moord tot de dood van haar dochter een feit was aanwezig [is] geweest in de woning zonder zich op enigerlei wijze te distantiëren van deze toedracht'. $\mathrm{Nu}$ is in de rechtspraak aanvaard dat niet-distantiëren een (bijkomend) argument kan zijn voor medeplegen. Ten Voorde betoogt echter in een reactie op deze zaak dat de rechter ten aanzien van de vaststelling van medeplegen te weinig oog had voor de culturele factor: 'Bood het kader dat haar cultuur haar biedt wel de ruimte om zich te distantiëren? ${ }^{64}$ Voorafgaande vraag is echter of dit wel relevant is voor het bewijs van medeplegen (vergelijk dezelfde vraag met betrekking tot de voorbedachte raad). Hoewel de Hoge Raad niet expliciet op dit punt ingaat, lijkt de uitspraak erop te wijzen dat het zich kunnen distantiëren geen vereiste is voor medeplegen. Dat maakt de mogelijke invloed van cultuur op de keuzevrijheid van de dader in zijn gedragsmogelijkheden natuurlijk niet irrelevant; het zal echter aan de orde komen bij de strafuitsluitingsgronden (ontbreken van schuld vanwege bijvoorbeeld psychische overmacht).

Schennis van de eerbaarheid, ontucht en belediging

In het voorgaande betroffen de cultuurverschillen direct de dader. Ook andere vragen rijzen, bijvoorbeeld indien bestanddelen zelf al sterk cultureel bepaald zijn, in het bijzonder het gedragingsbestanddeel. Te denken is vooral aan bestanddelen uit de zedendelicten, zoals 'eerbaarheid' (art. 239 Sr) en 'ontuchtige handelingen' (art. 246 $\mathrm{Sr}$ ). Schennis van (of aanstotelijk voor) de eerbaarheid wil zeggen: een gedraging die op onbehoorlijke wijze kwetsend is voor het geslachtelijke schaamtegevoel. ${ }^{65}$ In hoeverre spelen culturele (minderheids)opvattingen een rol bij de invulling van dit begrip? Met de eerbaarheid wordt bedoeld, aldus de Hoge Raad in het 'Chick'-arrest uit $1970,{ }^{66}$ 'de eerbaarheid als algemeen begrip zoals dat moet opgevat naar de hier te lande heersende zeden welke worden bepaald door de bij een belangrijke meerderheid van het Nederlandse volk levende opvattingen [curs. HDW]'. Het gaat dus om de heersende seksuele moraal van de rechtsgemeenschap. De seksuele moraal van een culturele minderheidsgroepering is in dit verband niet beslissend. Betekent dit dat bepalend is wat de meerderheid zélf aanstootgevend vindt? Een paar jaar eerder betoogde de A-G Langemeijer in zijn conclusie vóór HR 23 maart I965, NJ I965, 260 'dat het hier niet per se aankomt op wat aan de leden van de meerderheid persoonlijk aanstoot geeft, maar dat het zeer wel denkbaar is, dat een meerderheid aanstoot in ruimere zin neemt aan datgene waarvan het weet, dat het voor een respectabele minderheid kwetsend moet zijn'. Deze aanstoot in ruimere zin wordt ook wel de indi-

64. J. ten Voorde, Medeplegen en de culturele diversiteit in het strafrecht, NJB 2003, p. I235.

65. T.J. Noyon, G.E. Langemeijer, J. Remmelink, Het Wetboek van Strafrecht, Deventer: Gouda Quint (losbl.), aant. I bij art. 239. Het gaat dus niet, zoals bij de strafuitsluitingsgrond noodweer ex art. 4I Sr (zie § 7.3) om de persoonlijke, 'fysieke' seksuele integriteit.

66. HR I7 november I970, NJ I97I, 373 (Chick-arrest). 
recte aanstoot genoemd. Iets is volgens de heersende moraal ook aanstootgevend indien de meerderheid het aanstootgevend vindt, alléén omdat die meerderheid weet dat een minderheid het aanstootgevend vindt. In het genoemde 'Chick'-arrest wijst de Hoge Raad deze ruimere invulling echter af. Ook langs deze weg lijkt er dus geen ruimte voor (culturele) minderheidsopvattingen.

Bij 'ontuchtige handelingen', zoals in art. $246 \mathrm{Sr}$ (feitelijke aanranding van de eerbaarheid ${ }^{67}$ ), lijkt van eenzelfde standaard uit te worden gegaan. Het gaat om wat wel of niet 'algemeen sociaal-ethisch aanvaard' is, om 'maatschappelijk onwenselijk gedrag', waarbij de rechter ook weer moet letten op de opvattingen van een meerderheid van de bevolking. ${ }^{68}$ Dat betekent, vermoedelijk, dat het aftrekken van de hoofddoek van een moslima geen ontuchtige handeling is, ook niet als dat in deze cultuur als kwetsend voor het geslachtelijke schaamtegevoel zou worden opgevat. Ter vergelijking: de Maastrichtse rechtbank oordeelde dat iemand die, op de openbare weg, bij een aantal kinderen het onderbroekje had uitgetrokken en de broekjes had meegenomen, zich schuldig had gemaakt aan ontuchtige handelingen. ${ }^{69}$

De jurisprudentie geeft geen voorbeelden waarin deze interpretatie van de bestanddelen eerbaarheid en ontuchtige handelingen wordt toegepast in de context van culturele minderheidsopvattingen. Interessant is wel een recente zaak met betrekking tot opvattingen binnen een subcultuur. HR I5 januari 2008, LJN: BB7II4 betrof een geval van 'ongewenste intimiteiten' binnen een politiekorps. De verdachte was door het hof veroordeeld wegens het meermalen plegen van feitelijke aanranding van de eerbaarheid (art. $246 \mathrm{Sr}$ ). De verdediging had aangevoerd dat in bepaalde groepen anders wordt gedacht over wat ontuchtig is. De omgangsvormen binnen het politiekorps zouden zodanig zijn dat niet van ontucht gesproken kan worden. Het hof oordeelde echter dat de omstandigheid dat over ontucht in een bepaalde groep wellicht anders wordt gedacht, van geen betekenis is. Het cassatiemiddel dat hierover klaagt wordt door de Hoge Raad verkort afgedaan (art. 8I RO ${ }^{70}$ ). Ongetwijfeld zal hij het eens zijn geweest met de A-G Machielse:

'Het middel gaat ervan uit dat het begrip ontucht moet worden gedifferentieerd alnaargelang de opvattingen binnen de groep waarbinnen die handelingen hebben plaatsgevonden. Dat is evenwel niet een juiste invalshoek. Het gaat erom of de sociaal-ethische normen die in de samenleving draagvlak hebben bepaalde gedragingen als ontuchtig aanmerken, niet of de bij die gedragingen betrokkenen dat doen.'

67. Art. $246 \mathrm{Sr}$ : Hij die door geweld of een andere feitelijkheid of bedreiging met geweld of een andere feitelijkheid iemand dwingt tot het plegen van ontuchtige handelingen.

68. Noyon-Langemeijer-Remmelink, a.w., aant. 7 bij art. 239-254bis. Indirect kunnen culturele opvattingen dan nog wel een rol spelen. Dat handelingen vrijwillig tussen personen plaatsvinden, kan van invloed zijn op het al dan niet ontuchtige karakter ervan. Die vrijwilligheid kan weer een culturele achtergrond hebben.

69. Rechtbank Maastricht Io juli 2003, NJ 2003, 532.

70. Art. 8I Wet op de rechterlijke organisatie: Indien de Hoge Raad oordeelt dat een aangevoerde klacht niet tot cassatie kan leiden en niet noopt tot beantwoording van rechtsvragen in het belang van de rechtseenheid of de rechtsontwikkeling, kan hij zich bij de vermelding van de gronden van zijn beslissing beperken tot dit oordeel. 
Of een 'min of meer permissieve cultuur binnen het politiekorps heerste' doet er niet toe.

Vergelijkbare vragen kunnen rijzen bij een delict als belediging (art. $266 \mathrm{Sr}$ ). Beledigen is het aanranden van iemands eer. ${ }^{71}$ Volgens de Hoge Raad is een uitlating beledigend indien de uitlating de strekking heeft een ander bij het publiek in een ongunstig daglicht te stellen en hem aan te randen in zijn eer en goede naam. ${ }^{72}$ Vanzelfsprekend speelt de context waarin een uitlating wordt gedaan een grote rol. Maar hoeveel 'culturele ruimte' wordt aldus geboden? Iemand niet-meer-groeten wordt in bepaalde culturen wellicht als zeer kwetsend ervaren. Kan dat een belediging zijn? Van belang lijkt hier het door Noyon-Langemeijer-Remmelink besproken onderscheid tussen een normatief en een factisch eerbegrip. ${ }^{73}$ Een factisch eerbegrip kan uitgaan van de eigen gevoelens van de 'aangesprokene', het subjectieve eergevoel derhalve. Factisch is ook het sociologische eerbegrip, in welk geval van belang is of in het algemeen te verwachten was dat de uitlating als kwetsend zou worden ervaren. Bij een factisch eerbegrip bestaat ruimte om met culturele verschillen rekening te houden omdat een groepspecifieke of zelfs individuele maatstaf kan worden aangelegd. Het Nederlandse recht lijkt echter uit te gaan van een normatief eerbegrip. Onder eer wordt verstaan het respect dat iemand als mens, dus ieder mens, toekomt, waarop hij aanspraak mag maken. Dan ligt, zoals ook bij ontucht en aanstotelijk voor de eerbaarheid, een uniform criterium meer voor de hand.74 Volgens die maatstaf zal het niet-meer-groeten van iemand niet beledigend zijn.

\section{Bedreiging met geweld}

Soms bieden bestanddelen wel ruimte voor andere culturele opvattingen of fenomenen. Dat geldt bijvoorbeeld voor 'bedreiging met geweld'. Dit bestanddeel komt onder meer voor in feitelijke aanranding van de eerbaarheid: het door bedreiging met geweld iemand dwingen tot het plegen of dulden van ontuchtige handelingen (art. $246 \mathrm{Sr}$ ) en in verkrachting: het door bedreiging met geweld iemand dwingen tot het ondergaan van handelingen die (mede) bestaan uit het seksueel binnendringen (art. $242 \mathrm{Sr}$ ). In een verkrachtigingszaak bestond het bewezenverklaarde 'door dreiging met geweld dwingen' uit het (door verdachte) overtuigen van het slachtoffer van spirituele krachten c.q. haar daarmee onder druk zetten en haar toevoegen dat haar iets ergs zou overkomen, hetgeen kon variëren van een epilepsieaanval tot een hartaanval. ${ }^{75}$ Tevergeefs werd aangevoerd dat het aanwenden van bovennatuurlijke krachten om iemand vrees in te boezemen geen 'bedreiging met geweld' oplevert. Van bedreiging met geweld kan immers ook sprake zijn als de bedreiging weliswaar

7I. Of goede naam, maar dat onderscheid lijkt geen rol meer te spelen.

72. Zie bijv. HR 30 oktober 2001, NJ 2002, I29.

73. Noyon-Langemeijer-Remmelink, a.w., aant. 3 bij Boek II, Titel XVI.

74. Vgl. E. Hilgendorf in Strafgesetzbuch Leipziger Kommentar, Walter de Gruyter 2005, Anm. 38 vor § I85: 'der von der Menschenwürde geprägte Kerngehalt der Ehre (...) [ist] kulturunabhängig und steht in Form des "personalen Geltungswerts" jedem mit grundsetzlich gleichem Inhalt und im gleichem Umfang zu. Dagegen erlaubt die Figur des primär gesellschaftlich geprägten "sozialen Geltungswerts", auch Ehrvorstellungen zu berücksichtigen, die von den Vorstellungen der Deutschen Mehrheit abweichen.'

75. HR 2I februari i989, NJ I989, 668. 
in het algemeen geen indruk zou maken, maar in het voorliggende geval wel degelijk vrees heeft opgewekt. ${ }^{76}$ De Hoge Raad hanteert daarmee een subjectieve maatstaf. Niet een 'criteriumfiguur', maar het concrete, mogelijk bangelijke of goedgelovige slachtoffer is maatgevend voor de vraag of van bedreiging met geweld sprake is. Lindenberg laat zien dat dit bij dwangdelicten zoals verkrachting, feitelijke aanranding van de eerbaarheid en het algemene dwangdelict (art. $284 \mathrm{Sr}$ ), ook wenselijk is. De achterliggende rechtsbelangen, seksuele integriteit, persoonlijke vrijheid, verdienen deze bescherming. ${ }^{77}$

\section{Verschillen in 'ruimte voor cultuur'}

Bij het ene delict of het ene bestanddeel bestaat meer ruimte voor (afwijkende) culturele opvattingen of fenomenen dan bij het andere. Dat kan zich voordoen - zie de voorbeelden - bij delicten uit één en dezelfde titel (zedendelicten) en zelfs binnen één en dezelfde delictsomschrijving (art. $246 \mathrm{Sr}$ ). Dat laat zich goed verklaren. Ten eerste zijn doel en strekking van een strafbepaling van belang. Bij schennis van de eerbaarheid (art. $239 \mathrm{Sr}$ ) is er naar geldend recht geen ruimte voor het 'meenemen' van culturele (minderheids)opvattingen. Het gaat om de heersende seksuele moraal van de rechtsgemeenschap. Achterliggend rechtsgoed is de publieke moraal en de (enkele) inbreuk op de publieke moraal zonder meer is het strafbare feit. Hier rekening houden met afwijkende culturele (minderheids)opvattingen betekent dat het delict van karakter verandert. De publieke moraal staat dan niet meer centraal. Bij verkrachting (art. $242 \mathrm{Sr}$ ) kan een cultureel fenomeen als het aanwenden van bovennatuurlijke krachten beantwoorden aan het bestanddeel 'bedreiging met geweld'. Daardoor verandert de aard van het delict niet. De strafbaarstelling ziet op een afgedwongen inbreuk op de seksuele integriteit. Verkrachting is niet 'bedreiging met geweld ${ }^{\prime}{ }^{8}$ bedreiging met geweld is het dwangmiddel.

Het tweede punt is meer inhoudelijk. Met het bovenstaande is namelijk niet gezegd dat het rekening houden met minderheidsopvattingen bij delicten als schennis van de eerbaarheid of belediging onmogelijk is. Bestanddelen kunnen anders worden geïnterpreteerd, de wetgever kan ingrijpen. Waar het om gaat is dat bij delicten als schennis van de eerbaarheid en belediging iets heel anders op het spel staat dan bij een delict als verkrachting. Verkrachting kent een concreet slachtoffer, wiens seksuele integriteit in het geding is. Ter bescherming van dat slachtoffer is het, bij de interpretatie van 'bedreiging met geweld', wenselijk om met de belevingswereld van dat slachtoffer rekening te houden, ook indien die belevingswereld niet aansluit bij de dominante cultuur (of welke cultuur dan ook). Schennis van de eerbaarheid is 'slechts' een delict gericht tegen de verdraagzaamheid. Een inbreuk daarop is veel

76. HR 28 mei I996, DD 96.32I. Ook in mensenhandelzaken wordt op deze wijze vaak gedreigd met geweld. Zie bijv. Rechtbank Groningen I2 december 2000, LJN: AA8975.

77. K. Lindenberg, Strafbare dwang, Apeldoorn: Maklu 2007, p. 22I e.v.; zie ook p. I50 e.v. Daarmee wordt de strafbaarheid ook geenszins oeverloos uitgebreid. Die wordt immers beperkt - vooral doordat de dader 'opzet op het dwingen' moet hebben, wat onder meer betekent dat de dader moet weten dat het slachtoffer de beïnvloeding niet wilde en dat het slachtoffer de beïnvloeding niet of nauwelijks kon vermijden (p. I69 e.v.).

78. Bedreiging met geweld kan wel onder art. 285 Sr vallen (bedreiging met bepaalde ernstige misdrijven). Bij dit delict rijst dus dezelfde interpretatievraag. Zie Lindenberg, a.w., p. 223 e.v. 
minder ernstig - wordt dan ook met een veel lagere straf bedreigd - dan een (afgedwongen) inbreuk op de integriteit. Voor degenen die de meerderheidsopvatting over de eerbaarheid niet delen, staat er dus minder op het spel. Dit betekent niet dat bij delicten als schennis van de eerbaarheid of belediging aan de maatstaf van de meerderheidsopvatting móet worden vastgehouden. De vraag of dat wenselijk is wordt zelfs alleen maar indringender naarmate minderheden groter worden. ${ }^{79}$

\section{$7 \quad$ Cultuur en strafuitsluitingsgronden}

Het culturele aspect kan alleen meespelen indien dit 'verwerkt' kan worden in het Nederlandse strafrecht en dat geldt voor de strafuitsluitingsgronden, als onderdeel van dat recht, niet anders. De voor het onderwerp belangrijkste strafuitsluitingsgronden zullen de revue passeren.

\section{I Ontoerekenbaarheid}

Wat betreft de ontoerekenbaarheid van het feit aan de dader wegens gebrekkige ontwikkeling of ziekelijke stoornis van zijn geestvermogens (art. $39 \mathrm{Sr}$ ) wordt met een enkele opmerking volstaan. Het gaat hierbij, kortgezegd, om een psychische afwijking als reden voor niet-toerekening. Daarvan zal doorgaans bij de culturele dader geen sprake zijn. Het is ook, zoals Bloemink opmerkt, 'zeer onwenselijk om gedragingen die in een bepaalde cultuur meer dan in de westerse cultuur worden getolereerd en begrepen (...) als gedragingen te beschouwen die uit een geestelijke afwijking voortkomen. In veel gevallen wordt het stempel "gek" als nog meer stigmatiserend ervaren dan het stempel "crimineel". ${ }^{80}$ Wel komt het voor dat het feit slechts in verminderde mate kan worden toegerekend vanwege een ziekelijke stoornis en dat die stoornis, zoals een aanpassingsstoornis in de emoties, het gevolg is van 'acculturatieproblematiek'. ${ }^{8 \mathrm{I}}$ Dan is art. $39 \mathrm{Sr}$ niet van toepassing; de dader blijft strafbaar, maar de verminderde toerekenbaarheid zal doorwerken in de strafmaat. (Volledige) ontoerekenbaarheid komt eerder in beeld bij daders die in een trance of een staat van bezetenheid een strafbaar feit plegen. Aan een dergelijke toestand kunnen culturele fenomenen als winti of voodoo ten grondslag liggen. ${ }^{82}$

\subsection{Overmacht}

De dader is niet strafbaar indien hij 'een feit begaat waartoe hij door overmacht is gedrongen', aldus de zeer open formulering van art. 40 Sr. De dogmatiek onder-

79. Vgl. in dit verband A.C. 't Hart, Pornografie voorbij moralisme of permissiviteit, in: R.H. Haveman e.a. (red.), Seks, zeden en strafrecht, Deventer: Gouda Quint 2000, p. 20 e.v.

8o. Bloemink, a.w., p. 55,56 .

8I. Zie bijvoorbeeld Rechtbank Amsterdam 7 juli 2004, LJN: AP8622.

82. Zie ook R. H. Wormhoudt, Culturele achtergronden en strafrechtspleging. Winti, Proces I99I, p. IIO, III; F. Koenraadt en E. van Vloten, Forensisch psychiatrische verslaglegging en cultuurconflict: randprobleem in een randgebied?, NJB I982, p. 953-964. Zie bijv. HR 9 maart I999, NJ I999, 435; HR 27 juni 2000, NJ 2000, 605; Hof leeuwarden 5 november 2003, LJN: AN732I. 
scheidt tussen de (rechtvaardigende) overmacht-noodtoestand en de (schulduitsluitende) psychische overmacht. ${ }^{83}$

\section{Overmacht-noodtoestand}

In geval van overmacht-noodtoestand wordt de dader geconfronteerd met een conflict van rechtsbelangen (of plichten), het belang een bepaalde strafnorm na te leven versus een ander (maatschappelijk) rechtsbelang. Hij moet wel een keuze maken. In dit conflict heeft de dader, door te kiezen voor het andere belang en daarmee de strafwet te overtreden, een juiste, redelijke keuze gemaakt. Noodtoestand is dan ook een rechtvaardigingsgrond. Bij de beoordeling van de juistheid van de keuze staan vooral de beginselen van subsidiariteit en proportionaliteit centraal: had het conflict niet ook opgelost kunnen worden zonder overtreding van de strafwet, althans door een minder ernstig feit te begaan, en weegt het gediende belang wel zwaarder dan het opgeofferde (strafrechtelijke) belang. Daarnaast kunnen culpa in causa en een Garantenstellung een rol spelen.

Betrekkelijk probleemloos zijn de gevallen waarin iemand weliswaar door toedoen van zijn cultuur in een conflictsituatie is gebracht, maar waarbij het belang dat de dader laat prevaleren een algemeen erkend - niet (minderheids)cultuurgebonden zwaarwegend maatschappelijk belang is. Betrekkelijk probleemloos: onder omstandigheden kan het de dader dermate verwijtbaar zijn dat hij in de conflictsituatie is verzeild (culpa in causa), dat het beroep op overmacht niet slaagt. Principiëler ligt het - als het ware het andere uiterste - indien het door de dader gediende belang bestaat in de naleving van een culturele plicht als zodanig. Het gaat dan om het culturele verweer in zijn meest eenvoudige vorm (\$ 2): het verweer dat de dader van het culturele delict (een gedraging die strafbaar is naar Nederlands recht maar toelaatbaar volgens de normen van de sociale groep waartoe de dader behoort), toch niet strafbaar is en wel enkel en alleen omdat de gedraging toelaatbaar is volgens de normen van de sociale groep waartoe de dader behoort. Dit komt erop neer dat het belang culturele normen na te kunnen leven zonder meer zwaarder weegt dan het belang van naleving van de strafrechtelijke norm. De van de strafwet afwijkende culturele norm wordt dus boven de strafwet gesteld - in wezen wordt een absoluut recht op cultuur geclaimd. Van een afweging van belangen is in deze (extreme) visie dan ook helemaal geen sprake: het strafrechtelijk belang delft, ongeacht zijn gewicht, het onderspit. Maar waarom zou een belang zwaarder wegen dan het door de strafbepaling beschermde belang, alléén omdat het om een 'cultureel gedragen' belang gaat. ${ }^{84}$ Dat valt moeilijk in te zien. Terecht wijst Strijbosch op de bezwaren in een samenleving die tal van groepen met elk hun eigen cultuur kent: 'Elke justitiabele zou als lid van enigerlei subgroep in zo'n verweer zijn of haar delinquente handelen op cultuur kunnen terugvoeren en anarchie zou heersen in de samenleving. ${ }^{85}$ Een dergelijk 'eenvoudig' cultureel verweer is in de rechtspraktijk ook nooit aanvaard (en ook niet aangevoerd).

83. De volstrekte onmogelijkheid anders te handelen omdat de wilsvrijheid daartoe volledig ontbreekt - absolute overmacht - wordt niet bij art. 40 Sr ondergebracht; van een gedraging is dan geen sprake en vrijspraak is het gevolg. Zie ook hiervoor, $\S 2$, over de essentialistische visie op cultuur.

84. Zie hierover ook Bloemink, a.w.; Maris van Sandelingenambacht, a.w.

85. F. Strijbosch, Culturele delicten in de Molukse gemeenschap, NJB I99I, p. 67I. 
Tussen deze twee uitersten is wellicht nog plaats voor een andere vorm van 'culturele noodtoestand'. De gedachte is dan dat het (niet-wettelijk beschermde) belang niet bestaat in het kunnen naleven van culturele normen als zodanig, maar in het achter de concrete culturele norm gelegen belang, waarbij dat belang weliswaar geen algemeen erkend maatschappelijk belang is, maar wel erkend is binnen de cultuur van de dader. Men denke aan fenomenen als de familie-eer. Is hier enige ruimte voor een geslaagd beroep op noodtoestand? Men kan zich afvragen of de dader in zo'n geval wel een een rechtsbelang zwaarder laat wegen (is de familie-eer een rechtsbelang?) Die vraag gaat echter naadloos over in de vraag naar de juiste belangenafweging: mocht de dader het culturele belang zwaarder laten wegen dan het strafwettelijk beschermde belang? Bij de ernstige misdrijven met concrete slachtoffers (of gevaar daarvoor) zal de rechter altijd meer gewicht toekennen aan het belang van wetsnaleving (en verplichten mensenrechten hem daartoe). Maar ook in de overtredingensfeer, bij de lichtere, vaak slachtofferloze vergrijpen, zal niet snel anders worden geoordeeld. Daar heeft de wetgever conflictsituaties veelal ook voorzien en heeft hij al een belangenafweging gemaakt. Alsdan zal de rechter zich in beginsel bij de door de wetgever gemaakte afweging moeten neerleggen. Zoals eerder bleek kan die overweging ook hebben geleid tot een specifieke regeling ten gunste van andere culturen - zie de regelgeving ten aanzien van het rituele slachten en de lijkbezorging (§ 4.I). Maar ook dan zijn er vaak grenzen en is niet alles toegestaan. Dat geldt bijvoorbeeld voor de Hindoestaanse man die als onderdeel van een begrafenisrite as van een verbrand lichaam uitstrooit over een rivier en daarmee een milieuovertreding pleegt $^{86}$ (een voorbeeld aan de hand waarvan sommige schrijvers willen laten zien dat bij slachtofferloze delicten het culturele delict wellicht gerechtvaardigd zou kunnen worden). De wetgever heeft eind jaren negentig weliswaar de mogelijkheden van asbestemming uitgebreid door ten aanzien van de wijze waarop door de nabestaanden met de as wordt omgegaan geen nadere beperkingen meer te stellen. Hij wijst echter tevens expliciet op de beperking die andere wetgeving kan stellen, waarbij het geval genoemd wordt van asverstrooiing die in strijd is met (lagere) milieuwetgeving. 87

\section{Psychische overmacht}

In de praktijk wordt bij culturele delicten zelden een beroep op overmacht-noodtoestand gedaan. Dat ligt anders ten aanzien van de psychische overmacht. Bij psychische overmacht wordt op de dader een zodanige, van buitenaf komende druk uitgeoefend dat zijn wilsvrijheid wordt aangetast, terwijl weerstand bieden aan die druk redelijkerwijs niet gevergd kan worden. Er moet sprake zijn, aldus de Hoge Raad, 'van een van buiten komende drang waaraan de verdachte redelijkerwijze geen weerstand kon en ook niet hoefde te bieden'. ${ }^{88}$ Ligt bij de noodtoestand de nadruk op de juistheid, althans redelijkheid, van de keuze die de dader maakt, bij psychische overmacht is het de druk van de omstandigheden waardoor het maken van een onjuiste keuze de dader niet verweten kan worden. Het wordt dan ook gezien als een schulduitsluitingsgrond

86. Zie Kantongerecht Zevenbergen 3 februari I982, NJCM-Bulletin I982, p. 4I8 e.v.

87. Kamerstukken II I996-I997, 25272, nr. 3, p. 3.

88. HR 30 november 2004, NJ 2005, 94. 
(het feit is wel wederrechtelijk), waarbij de nadruk op de persoon van de dader ligt. De beoordeling van de psychische overmacht vergt zowel een psychologische toetsing (kón de dader weerstand bieden), als een normatieve (behóórde hij weerstand te bieden). Bij die normatieve toetsing spelen de beginselen van proportionaliteit en subsidiariteit een rol, zij het een wat andere dan bij de noodtoestand. Aan deze vereisten wordt hier minder objectief getoetst, meer afgestemd op de persoon van de dader: wat mag van deze persoon (redelijkerwijs) verwacht worden?

In de rechtspraak over culturele delicten wordt regelmatig een beroep gedaan op psychische overmacht. Dat laat zich eenvoudig verklaren, ervan uitgaande dat iemands cultuur of culturele achtergrond zijn vrijheid van handelen meer of minder kan beïnvloeden. De - algemeen gezegd - culturele omgeving zou dan de drang vormen die de wilsvrijheid van de dader beperkt en waardoor anders handelen redelijkerwijs niet gevergd zou kunnen worden. Om dat te beoordelen zal die culturele omgeving echter 'ontleed' moeten worden. Dan rijst ook al snel de vraag in hoeverre wel van een werkelijk cultureel verweer sprake is. Bestond de drang uit (alleen) het eigen culturele normenpatroon? Oefende het enkele gegeven dat, bijvoorbeeld, de familie-eer slechts beschermd kon worden door de strafbare gedraging te verrichten, een drang uit op de dader? Of werd de dader (eventueel óók) onder druk gezet door familieleden? En bestond die druk uit het confronteren met het culturele verwachtingspatroon, uit het dreigen met uitstoting uit de groep of uit 'gewoon' dreigen met geweld? Zeker het laatste geval laat zien dat bij een door anderen uitgeoefende druk al snel factoren kunnen meespelen die niet cultuurbepaald zijn, althans niet bepaald door de minderheidscultuur waartoe de dader behoort. Dat geldt overigens ook indien die druk van anderen er niet is. Overspel door de echtgenote of de wens tot echtscheiding kunnen ook bij de autochtone dader gevoelens van jaloezie en wraak oproepen en hem aanzetten tot strafbare gedragingen.

Hoewel vaak aangevoerd, is het beroep op psychische overmacht tot dusver in de rechtspraak altijd afgewezen. ${ }^{8} 9$ Vrijwel steeds betreft het levens- of geweldsdelicten begaan uit eerwraak, waarbij de bescherming van de eigen of familie-eer in het geding is. Dat aan het delict een eerwraakmotief ten grondslag ligt, zegt in dit verband nog niets, in het bijzonder niet dat de wilsvrijheid van de dader is aangetast. Integendeel, de dader kan uit volle overtuiging hebben gehandeld (zie ook hierna). Terecht stelde de Rechtbank Den Bosch:

'De vraag is niet of de aanwezigheid van een eerwraak-motief moet leiden tot een zwaardere of lichtere straf dan wanneer een dergelijk, cultureel bepaald motief niet aanwezig is, maar of dat eerwraak-motief en de daarmee verband houdende factoren (...) deze verdachte zo onder druk hebben gezet dat hij daaraan redelijkerwijs niet weerstand had kunnen bieden [curs. HDW]. 90

Hoewel de rechter doorgaans erkent dat de dader onder een zekere druk heeft gestaan - van familie en/of culturele achtergrond - wordt uiteindelijk toch onaanne-

\footnotetext{
89. Zie o.m. HR 20 november I979, NJ I980, I29; Hof Leeuwarden I9 juni 2000, LJN: AD8362. Hof Leeuwarden 5 november 2003, LJN: AN732I.

90. Rechtbank's-Hertogenbosch I3 februari 200I, LJN: AA9954.
} 
melijk geacht dat de dader in redelijkheid niet in staat is geweest zich van de strafbare gedraging te onthouden.

Van de psychologische toetsing is in de motivering van uitspraken vaak weinig terug te vinden, hetgeen er ongetwijfeld mee te maken heeft dat de rechter hier minder houvast heeft, althans dat zo voelt. Bij deze toetsing rijst immers de lastige vraag welke invloed cultuur op iemands handelen kan hebben (zie § 2). Indien echter een deskundige is ingeschakeld, ontkomt de rechter niet aan een standpuntbepaling. Een voorbeeld is de uitspraak van de rechtbank Den Bosch in de Veghelse eerwraakzaak van een aantal jaren geleden. ${ }^{9 \mathrm{I}}$ De rechtbank vond de stelling van de ingeroepen deskundige dat de verdachte 'onder onhoudbare druk van zijn familie en van zijn omgeving is gekomen om de familie-eer te redden' onvoldoende onderbouwd.

'De omstandigheid dat, zoals deze deskundige stelt, binnen de culturele context en de gezinscontext collectivistische waarden prevaleren boven individualistische belangen en dat in die constellatie het (westerse) begrip wilsvrijheid een illusie is, acht de rechtbank geen toereikende onderbouwing: enerzijds niet omdat niet valt in te zien dat prevalentie van collectivistische waarden geen enkele ruimte laat voor (individuele) wilsvrijheid, anderzijds niet omdat niet wordt duidelijk gemaakt waarom die druk vanuit de collectivistische waarden zo zwaar was dat verdachte daaraan geen weerstond kon noch hoefde te bieden.'

Deze rechter houdt er kennelijk geen culturalistisch (of essentialistisch) cultuurbegrip op na.

In de motivering van de verwerping van het beroep op psychische overmacht krijgt vooral de normatieve toets aandacht. Daarbij speelt vrijwel steeds de ernst van het gepleegde feit een grote rol: hoe ernstiger het gepleegde delict, des te eerder zal de rechter oordelen dat anders handelen redelijkerwijs gevergd kon worden. Daarnaast is aan de subsidiariteitseis vaak niet voldaan, waar de rechter ervan uitgaat dat de eerkwestie - soms óók volgens de eigen cultuur - op andere, minder ingrijpende wijze kan worden opgelost of dat de dader hulp had kunnen zoeken bij andere personen. ${ }^{92}$ Het is dus vooral de normatieve toetsing die aan een geslaagd beroep op psychische overmacht in de weg staat. Bij ernstige delicten wil de rechter er niet aan dat de invloed van de culturele omgeving op de wilsvrijheid zodanig kan zijn, dat het nalaten van de gedraging redelijkerwijs niet van de dader gevergd kon worden. ${ }^{93}$ Daarbij speelt wellicht ook het punt waarop Knigge, ${ }^{94}$ in navolging van Van Veen, 95 heeft gewezen, namelijk dat bij de aanvaarding van psychische overmacht een rechtspolitiek argument meespeelt. Dat wil zeggen: die aanvaarding hangt mede af van hetgeen de samenleving zich in dit opzicht kan veroorloven. Honorering van het

9I. Rechtbank's-Hertogenbosch I3 februari 200I, LJN: AA9954.

92. Soms is de toepassing van de subsidiariteitstoets wel heel weinig overtuigend. Volgens Rechtbank Amsterdam 7 juli 2004, LJN: AP8622, was gebleken dat de verdachte 'wel degelijk alternatieven had, met name het alternatief om niet te doen wat hij heeft gedaan [curs. HDW]'.

93. Vgl. ook B.F. Keulen, Het strafrecht en de overtuiging, in: Ontmoetingen, Voordrachtenreeks van het Lutje P.J.G., 2006, nr. I2, p. 24, 25.

94. Noot onder HR I4 oktober 2003, NJ 2005, I83.

95. Noot onder HR I7 september I992, NJ I993, 267. 
beroep op de dwang die van de eigen cultuur uitgaat, 'zou betekenen dat de (potentiele) slachtoffers van de gruweldaden waartoe die cultuur aanzet, geen adequate strafrechtelijke bescherming kan worden geboden. Aan de culturele dwang dient het strafrecht juist tegenwicht te bieden door een ernstig te nemen strafbedreiging.'

Het gaat er uiteindelijk om wat redelijkerwijs van de dader is te vergen. Dat kan uiterst moeilijk te beoordelen zijn. De persoon van de dader is van belang en daarmee kan ook diens culturele achtergrond een rol spelen. Maar wat redelijk is wordt op zichzelf niet bepaald door de dader of diens cultuur. Een goed voorbeeld is het vonnis van de Rechtbank 's-Gravenhage in de zaak van het meisje Mehak. ${ }^{96}$ Een uit India afkomstige Hindoestaanse vrouw wordt vervolgd wegens moord op haar (zeer jeugdige) dochter. Het meisje zou 'behekst' zijn en de moeder stond onder zware druk stond om daartegen iets 'te ondernemen'. Dat leidde tot verwaarlozing van het meisje en tot veelvuldig slaan, ook door anderen, met zwaar lichamelijk letsel en uiteindelijk de dood ten gevolg. Bij de bespreking van het beroep op overmacht komt de rechter tot de conclusie dat de moeder onvoldoende heeft gedaan om aan de druk het kind iets aan te doen te ontkomen en voegt daaraan toe:

'De rechtbank is zich ervan bewust dat dit oordeel mede berust op een keuze voor het toepassen van Nederlandse maatstaven [curs. HDW], terwijl verdachte van Indiase afkomst is en ook in een overwegend Indiase setting leefde, hetgeen kennelijk een naar westerse maatstaven onbegrijpelijke lijdzaamheid meebrengt. Omdat de gebeurtenissen toch in Nederland hebben plaatsgevonden, kiest de rechtbank ervoor de norm die strekt tot bescherming van de gezondheid en het leven van een klein kind door de moeder boven het belang van de moeder bij voorkoming van sociale uitsluiting te stellen, en aldus die lijdzaamheid niet als voor verdachte onvermijdelijk te accepteren.'

De keuze voor het toepassen van 'Nederlandse maatstaven' - opgevat als: maastaven van de Nederlandse rechtsorde - is terecht. Het kan er in deze context niet om gaan wat de dader redelijk vindt. Dat betekent niet dat de persoon van de dader of diens achtergrond niet van belang is. De vraag is immers wat volgens de Nederlandse rechtsorde van deze dader, mede gelet op diens achtergrond, redelijkerwijs gevergd kan worden.

Wat de motivering van de verwerping van het beroep op psychische overmacht betreft is tenslotte nog het volgende van belang. Nogal eens wordt gewezen op het recht van het 'thuisland', bijvoorbeeld dat naar Turks recht doding uit eerwraak ook een ernstig delict is en dat het voorziet in een aparte strafbepaling. ${ }^{97}$ Maar is dit relevant voor de beoordeling naar Nederlands recht? ${ }^{98}$ De gedachtengang van de rechter is waarschijnlijk: eerwraak heeft zijn wortels (onder meer) in de (of: een bepaalde) Turkse cultuur; de Turkse wetgever kent een aparte strafbepaling voor doodslag uit eerwraak en gaat er dus kennelijk al vanuit dat de culturele achtergrond bij een eerwraak niet strafuitsluitend werkt; waarom zou ik als Nederlandse rechter daar dan anders over denken? In die redenering zit iets aansprekends, maar logisch dwin-

96. Rechtbank's-Gravenhage I4 december 2007, LJN: BCo775.

97. Zie bijv. Rechtbank Dordrecht I2 januari I979, NJ I979, 2 I4.

98. Vgl. G.G.J. Knoops, Psychische overmacht en rechtsvinding, Deventer: Gouda Quint: 1998, p. 260. 
gend is zij niet. De (strenge?) maatstaf voor strafuitsluiting die de Turkse wetgever of rechter in dit opzicht hanteert, hoeft natuurlijk niet die van de Nederlandse rechter (minder streng?) te zijn.

Met het voorgaande is niet gezegd dat een beroep op psychische overmacht in ernstige culturele zaken nooit kans van slagen heeft. Dat hangt af - uiteraard - van de omstandigheden van het geval. Zo kan de (jeugdige) leeftijd van de dader van belang zijn, evenals het feit dat de druk uit de culturele omgeving de vorm van dreigementen richting de toekomstige dader heeft aangenomen. ${ }^{99}$ Maar dan gaat het - zie reeds hiervoor - ook niet meer zozeer om culturele factoren die de druk vormen en de wilsvrijheid mogelijk aantasten. ${ }^{\text {I0O }}$ Dergelijke factoren kunnen immers in het algemeen een rol spelen bij een beroep op psychische overmacht. Met het voorgaande is overigens evenmin gezegd dat een beroep op psychische overmacht bij lichte vergrijpen eerder kans van slagen heeft. Waarschijnlijk is in die gevallen de druk die op de dader is uitgeoefend ook minder groot.

\section{Gewetensbezwaren}

De culturele dader die zich succesvol kan beroepen op psychische overmacht is iemand wiens wilsvrijheid is aangetast. In sommige gevallen echter kan de culturele dader wellicht juist gezien worden als een 'overtuigingsdader', een dader die, zich zeer wel bewust van zijn culturele drijfveren en van de mogelijke consequenties van zijn handelen, 'gedwongen' door zijn geweten tot zijn daad komt. Zijn wil wordt niet uitgeschakeld door de culturele omgeving, maar hoogstens erdoor versterkt. ${ }^{\text {IOI }}$ In de literatuur is wel eens bepleit de overtuigingsdader een uitweg te bieden via de zogenaamde schulduitsluitende noodtoestand. ${ }^{102}$ De dader bevindt zich wel in een noodsituatie - wetsnaleving versus naleving van zijn overtuiging - maar het besluit zijn overtuiging te volgen kan niet gerechtvaardigd worden (dus geen noodtoestand), terwijl evenmin sprake is van aangetaste wilsvrijheid (dus evenmin psychische overmacht). Indien niettemin gezegd kan worden dat het gewetensbezwaar of de gewetensdrang onoverkomelijk is voor de dader, zou hij vrijuit moeten gaan. Hij heeft dan geen schuld omdat hij niet anders kon handelen, waarbij die onmogelijkheid anders te handelen wel een psychische onmogelijkheid is, maar niet een die is gebaseerd op 'desintegratie' in de wilsvorming.

De rechtspraak biedt echter geen enkele steun voor deze opvatting. Een geslaagd beroep op gewetensbezwaren of gewetensdrang - vaak gegoten in de vorm van overmacht - komt daarin niet voor. Gaat het om een overtuiging waarvoor de wetgever een afzonderlijke regeling heeft gemaakt, zoals (destijds) voor de gewetensbezwaren tegen militaire dienst, dan wordt die regeling uitputtend geacht, zodat voor een beroep op een strafuitsluitingsgrond wegens gewetensbezwaren verder geen ruimte

99. Vgl. ook F. Strijbosch, Eerwraak, onderzoek en strafrecht, NJB 200I, p. 889; Maris, a.w., p. I7II.

Ioo. Vgl. Maris van Sandelingenambacht, a.w., p. I7II.

IOI. Vgl. Maris van Sandelingenambacht, a.w., p. I7II; M.M. Dolman, Overmacht in het stelsel van strafuitsluitingsgronden, Nijmegen: Wolf Legal Publishers 2006, p. 2I9: 'de gewetensdader leeft zich in het feit uit'.

I02. W.A. Holland, Gewetensbezwaren en strafuitsluitingsgronden, Arnhem: Gouda Quint I989, p. 284 e.v. 
is. Is zo'n regeling er niet, dan is dat tevens het argument voor de rechter om aan te nemen dat de wetgever van strafuitsluitende werking van gewetensbezwaren niet wil weten.

\section{$7 \cdot 3 \quad$ Noodweer(exces)}

Een interessante strafuitsluitingsgrond voor het onderhavige onderwerp is noodweer: 'Niet strafbaar is hij die een feit begaat, geboden door de noodzakelijke verdediging van eigen of eens anders lijf, eerbaarheid of goed tegen een ogenblikkelijke, wederrechtelijke aanranding' (art. 4I lid I Sr). Noodweer is rechtsverdediging - de burger heeft soms een recht tot afweer van onrecht - en noodweer wordt dan ook als een rechtvaardigingsgrond aangemerkt. Zoals uit art. 4I Sr blijkt, is noodweer echter alleen toegestaan onder strikte voorwaarden. Vereist is een ogenblikkelijke wederrechtelijke aanranding van eigen of eens anders lijf, eerbaarheid of goed, de verdediging daartegen moet noodzakelijk zijn en voldoen aan de vereisten van proportionaliteit en subsidiariteit. Is de verdediging tegen zo'n aanranding wel noodzakelijk maar voldoet zij niet aan de eisen van proportionaliteit en subsidiariteit, dan is onder omstandigheden een beroep op (schulduitsluitende) noodweerexces mogelijk: 'niet strafbaar is de overschrijding van de grenzen van noodzakelijke verdediging, indien zij het onmiddellijke gevolg is geweest van een hevige gemoedsbeweging, door de aanranding veroorzaakt' (art. 4I lid $2 \mathrm{Sr}$ ).

Gelet op deze - uiteraard ook cultureel bepaalde - beperkende voorwaarden is direct al duidelijk dat in sommige culturen aanvaarde vormen van 'rechtsverdediging' wel eens moeilijk noodweer kunnen opleveren. Zo kan in een cultuur een belediging, waardoor iemands eer wordt geschonden, een legitimatie zijn voor een gewelddadige reactie van de beledigde. Naar Nederlands recht is in zo'n geval echter niet een rechtsgoed aangetast dat via noodweer beschermd mag worden. In het bijzonder is een belediging geen aanranding van de in art. 4I genoemde eerbaarheid (nog afgezien van de proportionaliteit van de reactie); daaronder wordt alleen de kuisheid op seksueel gebied, en wel in lichamelijke zin, verstaan. En indien wel iemands (seksuele) eerbaarheid is geschonden, zal een naar aanleiding daarvan door deze persoon of bijvoorbeeld een familielid uitgevoerde wraakactie evenmin gerechtvaardigd kunnen worden via noodweer. Aan straffeloosheid staat dan in de weg het vereiste dat de verdediging gericht moet zijn tegen een ogenblikkelijke aanranding: de ogenblikkelijkheid houdt niet alleen in dat de aanranding niet te ver in de toekomst mag liggen, maar ook dat zij nog niet is afgelopen, wat bij een wraakactie doorgaans het geval is. Om dezelfde reden zal een uit eer- of bloedwraak geplande doodslag of moord niet gerechtvaardigd kunnen worden. Daarnaast is bij dit soort wraakacties van een verdedigingswil eigenlijk geen sprake. Lastiger - op het eerste gezicht althans - is het uit de Turkse cultuur stammende fenomeen 'agir sözler'. Naar de vorm gaat het daarbij om een ernstige belediging, maar inhoudelijk heeft deze het karakter van een bedreiging met geweld of een levensbedreiging. Ook hier is de vraag of wel van een ogenblikkelijke aanranding sprake is. Van belang is dat daaronder niet alleen een daadwerkelijke aantasting van lijf, eerbaarheid of goed wordt verstaan, maar ook een 'onmiddellijk dreigend gevaar' voor zo'n aantasting. Volgens 
Wormhoudt ${ }^{\mathrm{IO} 3}$ zou 'agir sözler' - dus een belediging die neerkomt op een bedreiging met geweld of een levensbedreiging - al een onmiddellijk dreigend gevaar (voor aantasting van het lijf) kunnen opleveren, en daarmee een ogenblikkelijke aanranding in de zin van art. 4I Sr, waartegen verdediging is toegestaan. Dat is toch niet waarschijnlijk. Aldus raakt men immers ver verwijderd van het begrip 'onmiddellijk dreigend gevaar'. Daarmee wordt gedoeld op de fase onmiddellijk voorafgaand aan de daadwerkelijke aanranding. Bij de 'agir sölzer' hoeft het niet om die fase te gaan, omdat de verwerkelijking van de bedreiging niet meteen op de bedreiging hoeft te volgen. In dit soort situaties is de enige 'escape' voor de dader dat hij verontschuldigbaar dwaalde omtrent het recht, een vorm van afwezigheid van alle schuld (par. 7.5). Wellicht dacht de dader dat hij zich mocht verdedigen tegen een aantasting van zijn eer en goede naam of tegen een bedreiging met geweld. Alleen echter indien die dwaling verontschuldigbaar is, gaat hij vrijuit - en dat zal de rechter niet gemakkelijk aannemen.

Niettemin kunnen, net als bij het bewijs van ten laste gelegde bestanddelen, bij het vaststellen van de aannemelijkheid van de verschillende noodweervoorwaarden culturele gegevens een rol spelen. In de eerder genoemde zaak betreffende de uit bloedwraak voortgevloeide gewelddadige confrontatie tussen de twee Koerdische families C. en I., doet een lid van de familie I., verdacht van poging tot doodslag, een beroep op noodweer. Ten aanzien van de proportionaliteit van de verdediging overwoog het hof:

\footnotetext{
'Het hof is van oordeel dat het door verdachte gehanteerde geweld, te weten het afvuren van één schot, proportioneel is, gelet op de bewapening van minstens één van de leden van de familie [C.] met een vuurwapen, de afstand tussen verdachte en de gewapende man, de tussen de leden van de familie [C.] en [I.] bestaande bloedvete [curs. HDW], en de komst van de leden van de familie [C.] naar [woonplaats familie I.].'
}

Met de verwijzing naar - onder (veel) meer - de bloedvete - bedoelt het hof niet te zeggen dat bij een dergelijk cultureel fenomeen de proportionaliteit anders - namelijk naar de maatstaven van de cultuur waaruit het fenomeen stamt - wordt beoordeeld. Het bestaan van de bloedvete behoort wél tot de context waarbinnen de proportionaliteit van het schieten beoordeeld moet worden. Gelet op die context, zo kan 's hofs overweging heel goed geïnterpreteerd worden, is het zeer waarschijnlijk dat de aanrander het niet zou laten bij een mishandeling (bijvoorbeeld slaan met het pistool), maar dat het leven van de verdachte, de aangerande, op het spel stond. En dan kan de inzet van een zwaarder verdedigingsmiddel - schieten - naar maatstaven van de Nederlandse rechtsorde proportioneel en dus gerechtvaardigd zijn.

Een belangrijke vraag is vanuit welk gezichtspunt de aanwezigheid van de omstandigheden die de noodweersituatie constitueren moet worden beoordeeld. De beoordeling is niet ex nunc, maar ex tunc, een beoordeling van de feiten ten tijde van het handelen. Met noodweer als instituut van rechtshandhaving strookt niet dat voor

I03. Wormhoudt, a.w., p. 333 . 
deze ex tunc toetsing het subjectieve inzicht van de dader beslissend is. Objectivering is noodzakelijk. Interessant is in dit verband HR I8 september I989, NJ I990, 29I. Bij een ontmoeting met zijn nicht was de (Surinaamse) verdachte bang dat zij 'zwarte krachten' op hem zou kunnen overbrengen door hem aan te raken. Om te voorkomen dat zij hem zou aanraken en te bewerkstelligen dat zij weg zou gaan heeft verdachte haar de woorden toegevoegd: 'je moet oprotten anders steek ik je kapot'. De verdachte wordt vervolgd wegens bedreiging met enig misdrijf tegen het leven gericht (art. $285 \mathrm{Sr}$ ). Hij beroept zich op noodweer. Het optreden van de nicht - dreigen 'zwarte krachten' op hem over te brengen door hem aan te raken - zou een ogenblikkelijke aanranding vormen waartegen hij heeft zich mocht verdedigen (door middel van de bedreiging). De Hoge Raad verwerpt dit beroep omdat het optreden van de nicht 'in redelijkheid beschouwd niet zodanig bedreigend was voor de verdachte dat het kon worden aangemerkt als een "ogenblikkelijke aanranding" in de zin van art. 4I Sr'. Dat 'in redelijkheid' impliceert een zekere objectivering. Maar in welke zin?

Volgens annotator 't Hart laat het arrest juist door het gebruik van de woorden 'in redelijkheid' ruimte om onder omstandigheden wél noodweer aan te nemen. Het beroep op noodweer zou misschien kans van slagen hebben indien de gedachtegang van de dader zou passen in diens eigen Surinaamse achtergrond. 'Want de kernvraag is daarbij om wiens redelijkheid het gaat en welk redelijkheidsoordeel mag prevaleren.' Als het om de redelijkheid van de verdachte gaat, dan, zo lijkt 't Hart te zeggen, zou het dreigen zwarte krachten op hem over te brengen door hem aan te raken redelijkerwijs als een onmiddellijk dreigend gevaar en dus als een ogenblikkelijke aanranding kunnen worden beschouwd, namelijk indien en voor zover die gedachtegang past in de culturele achtergrond van de verdachte. Daarin zit een zekere objectivering - het moet wel passen in verdachtes cultuur - maar de vraag is of die voldoende is. Want uiteindelijk bepaalt zo verdachtes cultuur of het beroep op noodweer slaagt en daarmee dus de wederrechtlijkheid van zijn handelen. Zoals bij psychische overmacht, dient echter hier evenmin doorslaggevend te zijn wat de dader redelijk vindt of wat redelijk is volgens zijn cultuur. ${ }^{\text {IO4 }}$ De maatstaf voor redelijkheid moet ontleend worden aan de Nederlandse rechtsorde. Ook de meeste schrijvers vullen de 'redelijkheid' objectiever in dan 't Hart doet. Doorslaggevend is, aldus Machielse, niet de voorstelling die de dader zich redelijkerwijs mocht maken, maar 'of de goede, verstandige tweelingbroer van de verdachte, die zich loyaal tegenover de eisen der rechtsorde opstelt, ook zo zou hebben gehandeld'. ${ }^{105}$ En volgens De Hullu moet een onmiddellijke dreiging van aanranding 'ook voor derden aannemelijk zijn'. ${ }^{\text {I06 }}$ Uitgaande van deze meer objectieve invulling van de redelijkheid biedt de uitspraak van de Hoge Raad vermoedelijk geen ruimte om het dreigen zwarte krachten over te brengen onder omstandigheden toch als een ogenblikkelijke aanranding aan te merken. Die ruimte is er niet omdat - daar komt het eenvoudig gezegd op neer - het Nederlandse strafrecht niet gelooft dat iemands lijf 'aangetast'

I04. Ware dat anders, dan zouden de in het begin van deze paragraaf gegeven voorbeelden, die in eerste instantie toch geacht werden niet onder noodweer te vallen, ook in een ander licht komen te staan. I05. Noyon-Langemeijer-Remmelink, a.w., aant. I5 bij art. 4I.

Io6. De Hullu, Materieel strafrecht. Over algemene leerstukken van strafrechtelijke aansprakelijkheid naar Nederlands recht, Deventer: Gouda Quint 2006, p. 3 I2. 
kan worden door magische krachten. ${ }^{\text {I07 }}$ En als het langs deze weg niet aangetast kan worden, kan er evenmin langs deze weg een onmiddellijk dreigend gevaar daarvoor bestaan. Noodweer is dan niet mogelijk. De enige uitweg zou nog een beroep op verontschuldigbare dwaling zijn (zie par. 7.5).

In verband met de invulling van de 'redelijkheid' is ten slotte te wijzen op een recentere zaak, die ook in de literatuur aandacht heeft gekregen. Het betreft de al meermalen genoemde zaak over de uit bloedwraak voortgevloeide gewelddadige confrontatie tussen de twee Koerdische families C. en I., waarin een lid van de familie I., verdacht van poging tot doodslag, een beroep doet op noodweer. Daaromtrent overwoog het Arnhemse hof:

'Gelet op ontwikkelingen rond voormelde bloedwraak en hetgeen over de achtergrond daarvan bekend is, acht het hof aannemelijk dat de leden van de familie I. sinds de dood van M.C. (...) in 1994 letterlijk in doodsangst hebben geleefd en dat deze angst gerechtvaardigd was in het licht van hetgeen bekend is over de bloedvete. Het hof acht het aannemelijk dat verdachte de ontdekking van een auto met vier leden van de familie C., in de onmiddellijke omgeving van woningen van leden van de familie I. ervaren heeft als een onmiddellijke dreiging voor de aantasting van eigen of eens anders lijf nu minstens één lid van de familie hoogstwaarschijnlijk met een vuurwapen in zijn hand was uitgestapt [curs. HDW]. ${ }^{108}$

Het hof neemt hier aan, geheel conform de heersende leer, dat een aanranding niet alleen ogenblikkelijk is indien die al daadwerkelijk is ingezet, maar ook indien een 'onmiddellijk dreigend gevaar' daarvoor bestaat. In de literatuur is echter stevig gediscussieerd over de vraag vanuit welk gezichtspunt het hof de aanwezigheid van de 'onmiddellijke dreiging' voor de aantasting van het lijf heeft beoordeeld. Ten Voorde meent dat het hof de situatie heeft beoordeeld vanuit het perspectief van de dader en daarmee een subjectieve toets aanlegt. ${ }^{109}$ In feite zou daarmee een cultureel verweer door het hof zijn aanvaard. Volgens Jörg daarentegen heeft de beslissing 'niets te maken' met het accepteren van een cultureel verweer en is hier niets bijzonders aan de hand. Hij leest de overweging van het hof aldus, 'dat de verdachte vanwege de bloedvete kennelijk mocht [curs. HDW] menen dat de dreiging van een schietpartij reëel was. Zo reëel dat dit als een onmiddellijke dreiging voor een wederrechtelijke aanranding van eigen lijf of dat van familieleden kon worden beschouwd.' En: 'Het is om het even of de onmiddellijke dreiging van gewelddadigheden haar oorsprong in een bloedvete heeft, in een ripdeal, of in ander gedrag waarvoor men een afrekening mag vrezen. ${ }^{\text {IIO }}$ Met 'mocht menen' zal Jörg doelen op de redelijkheidstoets: het gebeuren was in redelijkheid beschouwd zodanig bedreigend voor de verdachte dat het kon worden aangemerkt als een ogenblikkelijke aanranding. Volgens Jörg gebruikt het hof hier dus het gegeven van de bloedvete

I07. Vg. De Hullu, a.w., p. 304: alsdan is het rechtsgoed niet 'daadwerkelijk in gevaar'.

Io8. Hof Arnhem I2 juni 2002, LJN: AE4029.

I09. J. ten Voorde, De berechting van culturele delicten en de flexibiliteit van het strafrecht, Ars Aequi 2005 , p. 77 e.v.; idem, Ars Aequi 2005, p. 253.

IIo. N. Jörg, Rechtstreekse acceptatie van een cultureel verweer?, NJB 2006, p. I694. 
voor de beoordeling van de aanwezigheid van een onmiddellijke dreiging op dezelfde wijze als waarop hiervóór dit gegeven voor de beoordeling van de proportionaliteit van belang werd geacht. Wat betreft de aanwezigheid van de onmiddellijke dreiging houdt die gebruikswijze in: in de context van de bloedwraak - en die is vermoedelijk: men komt niet om enkel te dreigen; hier wordt direct de daad bij het woord gevoegd - kan een gedraging een onmiddellijk dreigend gevaar voor aantasting van het lijf vormen, die diezelfde gedraging zónder die context niet vormt. ${ }^{\text {II }} \mathrm{Zo}$ bezien is er inderdaad niets bijzonders aan de hand.

Het kan goed dat het hof zijn overweging bedoeld heeft zoals door Jörg verwoord. Punt is alleen dat het hof het iets anders zegt. Het hof zegt namelijk niet dat de verdachte 'mocht menen' dat de dreiging reëel was. Het hof zegt dat het aannemelijk acht dat de verdachte de hele gang van zaken 'ervaren heeft' als een onmiddellijke dreiging. De objectivering die 'mocht menen' impliceert ('in redelijkheid'), impliceren de door het hof gebruikte bewoordingen niet. Jörg strijkt deze plooi recht wanneer hij zegt dat blijkens de overweging van het hof de verdachte 'kennelijk mocht menen' dat de dreiging van een schietpartij reëel was. Die lezing is ook gerechtvaardigd gelet op de omstandigheden van het geval.

Nogmaals: verschillen in 'ruimte voor cultuur'

Bij de bespreking van de doorwerking van cultuur op bestanddeel-niveau (par. 6) bleek dat bij het ene delict of het ene bestanddeel meer ruimte voor (afwijkende) culturele opvattingen of fenomenen bestaat dan bij het andere. Hier is te zien dat die verschillen er eveneens zijn tussen bestanddelen en anderzijds strafuitsluitingsgronden. Het dreigen zwarte krachten op iemand over te brengen is geen ogenblikkelijke aanranding van het lijf waartegen verdediging is toegestaan. Daarentegen oordeelde de Hoge Raad dat bedreiging met door voodoo-praktijken te verwerkelijken dodelijke gevolgen wel bedreiging met geweld in de zin van art. $242 \mathrm{Sr}$ (verkrachting) kan opleveren. Dit verschil in 'openheid' duidt geenszins op een tegenstrijdigheid en hoeft, om dezelfde reden als bij verschillen tussen delictsbestanddelen op dit punt, geen verwondering te wekken. ${ }^{\mathrm{II} 2}$ Ter bescherming van het slachtoffer van een afgedwongen inbreuk op diens seksuele integriteit is het, bij de interpretatie van 'bedreiging met geweld', wenselijk om met de belevingswereld van dat slachtoffer rekening te houden. Bij de uitleg van ogenblikkelijke aanranding van het lijf in het kader van noodweer, gaat het om de vraag of de dader vrijuit moet gaan omdat het door hem gepleegde strafbare feit gerechtvaardigd zou zijn. Dat is een geheel andere context, die het verschil in interpretatie kan verklaren en rechtvaardigen. ${ }^{\mathrm{II} 3}$ Overigens is hiermee niet gezegd dat bestanddelen van strafuitsluitingsgronden, net als delictsbestanddelen, niet ruimer geïnterpreteerd zouden kúnnen worden, of dat de wet niet

III. Zo reeds Wolswijk, a.w., p. 264 .

II2. Anders Huisman, a.w., p. 84 .

II3. Hetzelfde speelt bij de verhouding tussen 'dwang' als bestanddeel en overmacht als strafuitsluitingsgrond. Dwingen veronderstelt dat hetgeen waartoe de ander is gedwongen voor de gedwongene redelijkerwijs onvermijdelijk was. Bij psychische overmacht kan naleving van de strafwet redelijkerwijs van de dader niet worden gevergd. De onvermijdelijkheid in de context van dwingen hoeft niet even streng beoordeeld te worden als de onvergbaarheid in de context van overmacht. Zie hierover Lindenberg, a.w., p. I45 e.v. 
gewijzigd zou kúnnen worden. ${ }^{\mathrm{II} 4}$ Het gaat erom dat de vraag of dat wenselijk is niet zo maar beantwoord kan worden met een beroep op een ruime interpretatie die elders, in een andere context wordt gehanteerd.

\subsection{Tuchtigingsrecht, toestemming}

Naast wettelijke strafuitsluitingsgronden kent het Nederlandse strafrecht buitenwettelijke strafuitsluitingsgronden. Het bestaan van een algemene ongeschreven rechtvaardigingsgrond 'ontbreken van de materiële wederrechtelijkheid' is zeer omstreden. Dat geldt echter niet voor enkele 'verbijzonderingen': niet in de strafwet omschreven, maar wel aan de positieve rechtsorde ontleende gronden die de wederrechtelijkheid van de gedraging doen ontbreken. Van die gronden verdienen een paar kort de aandacht.

Het gebruik van geweld jegens kinderen in het kader van de opvoeding is in sommige culturen geaccepteerd. Ook naar Nederlands recht bestond tot voor kort een zeker tuchtigingsrecht van ouders ten opzichte van hun kinderen, waardoor bepaalde mishandelingen niet strafbaar waren. Het tuchtigingsrecht fungeerde aldus als een (strafrechtelijk) ongeschreven strafuitsluitingsgrond. Dit ouderlijk tuchtigingsrecht is echter komen te vervallen (par. 4.I). In sommige (islamitische) culturen heeft de man ook een dergelijk recht ten opzichte van zijn vrouw. Het is geoorloofd - kan zelfs geboden zijn - dat de man ('proportioneel') zijn vrouw slaat. Naar Nederlands recht bestaat dit recht niet. Met Remmelink kan het spreken van een tuchtigingsrecht van de man ten aanzien van zijn vrouw 'eigenlijk absurd' genoemd worden. ${ }^{\text {II5 }}$ Ook De Hullu wijst erop dat '[n]iet elk cultureel gedragen tuchtigingsrecht (...) zo maar wordt aanvaard, het moet om een breed gedragen maatschappelijke acceptatie gaan'. ${ }^{\mathrm{II} 6}$ Juist in dit soort situaties kan echter ook een andere ongeschreven rechtvaardigingsgrond meespelen: de toestemming. Het kan zijn dat de vrouw, ook vanuit een culturele achtergrond, ermee instemt dat de man haar op deze wijze 'corrigeert'. ${ }^{\text {II7 }}$ Aan een gedraging kan toch het strafbare karakter ontbreken wanneer voor die gedraging toestemming is gegeven. Dat kan echter alleen onder bepaalde voorwaarden. Ten eerste dient werkelijk toestemming te zijn gegeven; de toestemminggever moet niet onder dwang hebben gehandeld. Daarnaast dient bedacht te worden dat de toestemming over het algemeen niet een zelfstandige rechtvaardigingsgrond is, in die zin dat zij steeds wordt gereguleerd door de eisen die de rechtsgemeenschap stelt. Remmelink zou in het onderhavige geval de toestemming daarom in strijd achten met de 'openbare orde'. Tegelijk erkent hij dat het niet eenvoudig ligt, gelet op het feit dat op ander vlak - seks, sport, kloosterlingen die zich aan bepaalde tuchtigingen onderwerpen (vrijheidsberoving) de toestemming wel allerlei uitwassen legitimeert. ${ }^{\text {II8 }}$ De vragen liggen hier vermoedelijk in wezen niet anders dan bij de interpretatie van bepaalde delictsbestanddelen, zoals schennis van de eerbaarheid en ontuchtige handelingen (par. 6).

\footnotetext{
II4. Vgl. De Hullu, a.w., p. 362 .

II5. J. Remmelink, Mr. D. Hazewinkel-Suringa's Inleiding tot de studie van het Nederlandse strafrecht, Deventer: Gouda Quint I996, p. 359.

II6. De Hullu, a.w., p. 339 .

II7. Vgl. ook L. T. Wemes, Strafrecht. Tekst \& Commentaar, aant. I3 bij Boek I, Titel III, Inleidende opmerkingen.

II8. Remmelink, a.w., p. 359 .
} 


\subsection{Verontschuldigbare rechtsdwaling (ongeschreven schulduitsluitingsgrond)}

Het Nederlandse strafrecht kent een algemene, overkoepelende ongeschreven schulduitsluitingsgrond: afwezigheid van alle schuld. Van de verschillende gronden die de schuld afwezig doen zijn, is in dit verband vooral de verontschuldigbare rechtsdwaling mogelijk relevant: de dader wist niet én hoefde ook niet te weten dat wat hij deed wederrechtelijk was. Dwaling omtrent de wederrechtelijkheid kan zich ook weer in verschillende verschijningsvormen voordoen. De dwaling kan betrekking hebben op het bestaan (überhaupt) van een strafbaarstelling (van bijvoorbeeld bigamie). Hier dicht tegenaan ligt de dwaling omtrent de toepasselijkheid van een - de dader op zich wel bekende - strafbaarstelling op zijn gedraging. Men kan denken aan het geval van meisjesbesnijdenis waarbij de dader wel weet dat mishandeling strafbaar is, maar niet weet dat vrouwenbesnijdenis mishandeling oplevert. Ten slotte kan de dader, die wel weet dat zijn gedraging strafbaar is gesteld, nog dwalen omtrent de toepasselijkheid van een strafuitsluitingsgrond, zoals putatieve noodweer (de dader dacht bijvoorbeeld dat hij zich mocht verdedigen tegen een belediging, zie par. 7.3).

Op het eerste gezicht ligt een beroep op verontschuldigbare rechtsdwaling bij culturele delicten voor de hand. Hoe goed voorstelbaar is niet dat iemand uit een andere cultuur onbekend is met wat hier wederrechtelijk is, zeker als die wederrechtelijkheid zo cultuurbepaald is. Toch zal het beroep in het algemeen niet gemakkelijk slagen, omdat aannemelijk zal moeten zijn dat de dader verontschuldigbaar dwaalde omtrent het wederrechtelijke van zijn gedraging. Het gaat daarbij, net als bij psychische overmacht, om een normatieve toetsing. Het - op zichzelf wellicht begrijpelijke - gebrek aan affiniteit met het Nederlandse strafrecht zou een succesvol beroep zelfs nog moeilijker kunnen maken: juist vanwege dat gebrek heeft de dader de plicht ervoor te zorgen dat hij op de hoogte raakt; hij weet toch dat de normen van dat strafrecht wel eens kunnen afwijken van die van zijn cultuur. ${ }^{\text {II } 9}$ Daarnaast is juist bij de culturele dader van belang wat nu precies aan de dwaling ten grondslag ligt. De dader die zegt te hebben gedwaald omtrent de wederrechtelijkheid vanwege de geoorloofdheid of zelfs wenselijkheid van zijn gedraging volgens zijn eigen cultuur, dwaalt niet verontschuldigbaar. De dader verricht zijn gedraging dan niet uit onwetendheid. De dwaling - laat staan de eventuele verschoonbaarheid ervan - staat in wezen niet meer centraal.

In de (gepubliceerde) rechtspraak over culturele zaken wordt het verweer zelden gevoerd. Een van de weinige gevallen is het recente HR 25 maart 2008, NJ 2008, 195. Verdachte, een vrouw van Angolese afkomst, is veroordeeld ter zake van (onder meer) het medeplegen van mishandeling van haar kind. $\mathrm{Zij}$ had het kind met de hand, met een stok en met een sandaal op het lichaam en/of het hoofd geslagen. Volgens de verdediging heeft de verdachte verontschuldigbaar gedwaald omtrent de ongeoorloofdheid van haar handelen. De verdachte verbleef tot voor kort in asielzoekerscentra en had in de periode daarna alleen omgang met Angolezen. Het slaan van kinderen zou in de Angolese cultuur normaal zijn. Het Hof verwierp dit verweer als volgt: 'De door de raadsman aangevoerde stelling dat de verdachte heeft gehandeld

II9. Zo wordt ook van de buitenlandse toerist verwacht dat hij zich op de hoogte stelt van de voor hem mogelijk relevante wetgeving. Júist van hem, die immers weet dat hij zich in een voor hem vreemde rechtsorde begeeft, wordt dit verwacht. 
in verontschuldigbare dwaling omtrent het recht, op de grond dat zij onbekend was met de Nederlandse normen en het slaan van kinderen in Angola gebruikelijk is, vindt geen steun in het recht en kan derhalve niet worden aanvaard.' Daarmee lijkt het hof de mogelijkheid dat cultuurverschillen tot verontschuldigbare rechtsdwaling kunnen leiden geheel uit te sluiten. ${ }^{\mathrm{I} O}$ Dat doet de Hoge Raad niet. Toch had het Hof in casu het verweer slechts kunnen verwerpen omdat

'ter onderbouwing van het verweer [is] aangevoerd dat het in Angola gebruikelijk/normaal is dat kinderen worden geslagen, doch niet dat dit in Angola rechtens geoorloofd is, en evenmin dat en waarom de verdachte ten tijde van de in de bewezenverklaring omschreven gedragingen, waaronder het slaan van P., meende en mocht menen dat die gedragingen naar Nederlands recht geoorloofd zijn'.

Zoals ook bij de verwerping van een beroep op psychische overmacht bij eerwraak wel gebeurt (par. 7.2), wordt hier verwezen naar het buitenlandse recht. Ten aanzien van het beroep op psychische overmacht is opgemerkt dat de strafbaarheid naar buitenlands recht geen logisch dwingende reden is om dit verweer te verwerpen. Dat geldt ook voor het beroep op rechtsdwaling. Wellicht dwaalde de verdachte ook wel omtrent zijn 'eigen recht'. Indien de verdachte van dat recht wel op de hoogte is, heeft het verweer inderdaad geen kans van slagen. Dan weet hij immers dat zijn culturele norm in strijd kan zijn met het recht. Alsdan is moeilijk voor te stellen dat, zo hij al werkelijk dwaalde omtrent het Nederlandse recht, deze dwaling verontschuldigbaar is.

\section{$8 \quad$ Culturele factor in de straftoemeting}

Welke rol speelt de culturele achtergrond van het delict en de dader ${ }^{\mathrm{I2I}}$ bij de straftoemeting? Door het ontbreken van bijzondere strafminima per delict en zelfs de moge-

I20. Aldus ook de A-G Knigge, die deze mogelijkheid wél wil openlaten. Niet ongeestig is overigens de volgende passage uit zijn conclusie: 'De steller van het middel geeft er blijk van op de hoogte te zijn van HR 4 oktober 2005, NJ 2007, I92 waarin de Hoge Raad de verwerping van een beroep op het ouderlijk tuchtigingsrecht niet onbegrijpelijk oordeelde, in aanmerking genomen dat het kind (een meisje van 15 jaar) in het gezicht werd geslagen waardoor het stekende pijn ondervond. Volgens de steller van het middel zou dat anders kunnen liggen als het om een jongetje van 8 à ro jaar gaat. Indien dit serieus gemeend is, blijkt daaruit dat ernstige vormen van rechtsdwaling inderdaad voorkomen.'

In dit verband zij nog opgemerkt dat het onderhavige probleem juist bij kindermishandeling vereenvoudigd is door het vervallen van het ouderlijk tuchtigingsrecht. Indien wel een zeker tuchtigingsrecht bestaat, kan, indien de grenzen niet heel duidelijk zijn, gemakkelijker gedwaald worden omtrent de geoorloofdheid dan wanneer dit recht in het geheel niet bestaat.

I2I. Buiten beschouwing blijft de cultuur van het slachtoffer, die ook relevant kan zijn voor de ernst van het feit. Zie bijvoorbeeld Rechtbank Haarlem I9 juli 2006, LJN: AY478I: Verdachte was in bezit van eerder opgenomen beelden van het slachtoffer waarbij zij zich naakt toont voor de webcam. Onder de dreiging deze beelden aan de vader van het slachtoffer te geven en te verspreiden via internet, heeft verdachte de vrouw gedwongen tot het plegen van ontuchtige handelingen. Verdachte heeft de vrouw zich laten uitkleden voor haar webcam enz. Het slachtoffer is onder de grote druk die verdachte op haar uitoefende en ter bescherming van de eer van haar familie, bezweken. De rechtbank rekent verdachte haar gedragingen zwaar aan. Als Turkse vrouw wist zij welke impact het tonen van de beelden zou hebben. Een aparte categorie vormen ook 'hate crimes'. Zie hierover P.C. Bogert, Discriminatoir en rascistisch geweld zwaarder bestraft?, DD 2007, p. 748 e.v. 
lijkheid van schuldigverklaring zonder oplegging van straf (art. 9a Sr), heeft de Nederlandse rechter een grote straftoemetingsvrijheid. Hij kan rekening houden met alle omstandigheden van het geval, waaronder de aard en ernst van het feit, de omstandigheden waaronder het feit is begaan en de persoon van de dader. De (weinige) wettelijk erkende strafuerhogings- en strafverlagingsgronden zijn hier niet relevant. De omstandigheden die een rol spelen bij de beoordeling van de strafuitsluitingsgronden kunnen natuurlijk wel van belang zijn bij de straftoemeting. Het duidelijkst is dat wanneer het strafbare feit de dader slechts in verminderde mate kan worden toegerekend vanwege een ziekelijke stoornis. Een stoornis kan het gevolg zijn van 'acculturatieproblematiek' (par. 7.I). Strafuitsluiting ex art. $39 \mathrm{Sr}$ is in dat geval niet aan de orde, maar de verminderde toerekenbaarheid werkt wel strafverlagend.

'De centrale vraag is of cultuur een reden kan zijn om een lichtere of juist een zwaardere straf op te leggen.' ${ }^{\text {I22 }}$ Waar cultuur niet leidt tot strafuitsluiting, komt het inderdaad aan op de invloed bij de straftoemeting. Daarover lijkt nog grote onduidelijkheid te bestaan. ${ }^{\mathrm{I} 23}$ Soms wordt in een zaak met een culturele achtergrond in de strafmotivering niets over die achtergrond gezegd. Soms ook wordt wel naar de culturele achtergrond verwezen, maar laat de rechter in het midden welke rol deze uiteindelijk speelt. ${ }^{\text {I24 }}$ De 'centrale vraag' of cultuur strafverlagend of juist verhogend moet werken, kan echter niet in zijn algemeenheid beantwoord worden. Zoals ook bij de psychische overmacht, dient daartoe eerst duidelijk te worden waaruit de culturele achtergrond in het concrete geval bestaat. Indien die bestaat in een op de dader uitgeoefende druk door de familie om het delict te plegen omdat de familieeer hersteld moet worden, is dat een geheel andere achtergrond dan wanneer de dader uit volle (culturele) overtuiging het feit heeft begaan. Zeer terecht overwoog de Rechtbank 's-Hertogenbosch, die ook het beroep op psychische overmacht genuanceerd benaderde (par. 7.2),

'dat het niet gaat om de vraag of in zijn algemeenheid in strafzaken culturele achtergronden tot straffeloosheid, strafverhoging of strafvermindering zouden moeten leiden, maar of en zo ja, op welke wijze dergelijke achtergronden in het concrete geval van een individuele strafzaak de verdachte hebben gevormd c.q. beïnvloed. Dat is onderdeel van het in elke strafzaak uit te voeren onderzoek naar de persoon van de verdachte. ${ }^{\text {I25 }}$

De noodzaak tot nuancering is bij de straftoemeting misschien nog wel groter dan bij de vraag naar de strafuitsluitingsgronden. Het verschillend karakter van de strafuitsluitingsgronden dwingt als vanzelf ertoe aan te geven in welke zin de culturele

I22. M.L. Haimé, Culturele diversiteit en rechterlijke macht, in: E. Bauw e.a. (red.), Mijnheer de voorzitter. Liber amicorum A.H. van Delden, Den Haag: Boom Juridische uitgevers 2007, p. I37.

123. Ook op dit punt weten advocaten soms niet of ze er goed aan doen om de culturele factor in te brengen (zie ook noot 56).

124. Zie ook Hof Arnhem 5 september 2002, LJN: AE733: 'Zo de culturele achtergrond al strafuerminderend zou kunnen werken [curs. HDW], wordt dit tenietgedaan door het belang van de generaal preventieve werking van de straf.' Dat is onbevredigend. De achtergrond werkt strafverminderend of niet. Ceteris paribus moet in het eerste geval de straf lager zijn dan in het tweede geval.

I25. Rechtbank's-Hertogenbosch I3 februari 200I, LJN: AA9954. 
achtergrond van belang is (waarom zou de culturele achtergrond een drang vormen waaraan geen weerstand kon worden geboden? waarom maakt de culturele achtergrond dat sprake is van verontschuldigbare rechtsdwaling). Die vanzelfsprekende 'dwang' ontbreekt bij de straftoemetingsvraag.

De praktijk - in de vorm van de strafmotivering in concrete zaken - laat zien dat culturele factoren zeer verschillend in de straftoemeting kunnen doorwerken. ${ }^{\text {I26 }}$ Indien de culturele achtergrond erin bestaat dat er een druk op de dader is uitgeoefend om het delict te plegen en die druk de wilsvrijheid van de dader heeft aangetast, zij het niet voldoende om psychische overmacht aan te nemen, houdt de rechter daarmee in het algemeen rekening in voor de verdachte gunstige zin. ${ }^{127}$ Zo kan een door anderen uitgeoefende druk om het delict te plegen strafverminderend werken. ${ }^{\mathrm{I} 28}$ Heel duidelijk is dat in het geval een minderjarige door zijn ouder tot het plegen van het delict wordt aangezet. ${ }^{\text {I29 }}$ Dat lijkt onproblematisch en is ook niet bijzonder. Een door anderen uitgeoefende druk kan in het algemeen maken dat de mate van schuld minder is, of die druk cultuurbepaald is of niet. ${ }^{13^{\circ}}$ Ook zonder beïnvloeding van derden kan de dader zich onder druk gezet voelen door het culturele verwachtingspatroon. De Nederlandse rechter lijkt ook daarmee rekening te houden. Als cultuur inderdaad dit effect op mensen kan hebben, is daar niets op tegen - dat geldt voor elke 'achtergrond', voor elke 'bron' van druk. Vanzelfsprekend is van belang na te gaan óf de culturele achtergrond deze rol heeft gespeeld. Het plegen van het delict kan immers ook het gevolg zijn geweest van gevoelens die met die cultuur niets te maken hebben (gekwetstheid, jaloezie, haat) en die ook bij de niet-culturele dader kunnen spelen.

De dader kan het delict ook gepleegd hebben enkel omdat dit 'paste' in zijn cultuur. Een daarop gestoeld verweer komt neer op het culturele verweer in zijn meest eenvoudige vorm: de gedraging is verricht omdat zij toelaatbaar of geboden is volgens de normen van zijn cultuur (par. 2). Dit is niet alleen geen grond voor strafuitsluiting (noodtoestand, psychische overmacht), het wordt doorgaans evenmin gezien als een grond voor strafuermindering: 'dat verdachte kennelijk in de mening verkeerde dat de moord op zijn tante noodzakelijk was om de eer van de familie te redden (...) doet aan de strafwaardigheid van die moord niets af'. ${ }^{\text {I3 }}{ }^{\mathrm{I}}$ Wanneer de culturele achtergrond uit niets meer bestaat dan het 'kale' motief, zonder dat dit gepaard gaat met enige druk die de wilsvrijheid van de dader aantast (althans volgens de rechter), lijkt er inderdaad geen reden voor strafvermindering. Nogal eens kent de Nederlandse rechter aan het eerwraakmotief juist een strafverzwarende

I26. Zie ook J. ten Voorde, Het zwaarder straffen bij culturele delicten. Feit of fictie, Proces 2004, p. I24 e.v.

I27. Dat wil niet zeggen dat de straf per saldo lager uitvalt. Er kunnen daarnaast factoren zijn, eveneens cultuur-gerelateerd, die juist strafverzwarend werken, zoals overwegingen van generale preventie; zie de in noot 124 geciteerde overweging.

I28. Zie bijv. Hof Leeuwarden I9 juni 2000, LJN: AD8 362.

I29. Rechtbank's-Hertogenbosch I3 februari 200I, LJN: AA9954.

I30. Ter vergelijking: ongunstige sociale omstandigheden kunnen een strafverlagend effect hebben. De ongunstige omstandigheden kunnen een culturele achtergrond hebben. De culturele achtergrond als zodanig heeft dan geen strafverlagend effect.

I3I. Rechtbank Haarlem 9 mei 200I, LJN: ABI503. Vgl. ook Rechtbank Dordrecht 30 december I999, LJN: AA40I9. 
werking toe. Dat gebeurt om verschillende redenen. ${ }^{\mathrm{I} 32}$ Een daarvan is het aspect van eigenrichting: 'Iedere vorm van eigenrichting en daarmee ook conflicten als de onderhavige bloedwraak zijn binnen de Nederlandse samenleving volstrekt onacceptabel. ${ }^{\text {I33 }}$ De term eigenrichting is in dit verband wellicht misleidend, althans voor zover deze toch een zeker recht aan de kant van de dader suggereert - hij had dat alleen niet in eigen hand mogen nemen. Maar niet de eigenrichting als zodanig maakt het eerwraakdelict zo ernstig; het is vooral de enorme wanverhouding tussen aanleiding (eerkrenking) en daad (moord of geweld). Iets daarvan komt tot uiting in een andere soort motivering:

'Het motief van deze moord is gelegen in het feit dat het slachtoffer de eer van haar familie geschonden had; zij was ongehuwd zwanger geraakt van een man die geen moslim is. Moord is een van de ernstigste delicten uit het Wetboek van Strafrecht. (...) $\mathrm{Nu}$ in het onderhavige geval het motief van de moord is gelegen in eerwraak, impliceert dit misdrijf tevens een miskenning van het (in ieder geval in Nederland bestaande) recht van de vrouw om haar leven in te richten op de wijze die zij zelf verkiest.' ${ }^{\text {,34 }}$

Aanleiding voor de moord is het verrichten van een gedraging waartoe juist het volste recht bestaat en dat makt de 'eigenrichting' des te ernstiger. Dat is overigens geen argument om van het eerwraakmotief toch een wettelijke strafverzwaringsgrond te maken (geheel afgezien van de bewijsproblematiek). Zó bijzonder is het eerwraakmotief niet in vergelijking met sommige andere verwerpelijke motieven. Want kan, zoals de minister opmerkte, een moord begaan uit winstbejag niet minstens zo verwerpelijk zijn als een eergerelateerde moord (par. 4.I)?

Tenslotte leiden overwegingen van preventie soms tot een zware bestraffing: 'Voorts dient bij de straftoemeting het generaal-preventieve element een rol te spelen, als signaal aan de samenleving dat "namus" kwesties in geen enkel geval in

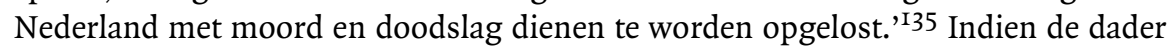
het (volstrekt) ongeoorloofde van zijn handelen niet inziet en overtuigd blijft van de juistheid ervan, kan om reden van speciale preventie een zware straf geïndiceerd zijn: 'Voorts acht de rechtbank van belang dat verdachte nog immer niet lijkt in te zien dat zijn handelen verkeerd is geweest, gelet op zijn verklaring ter terechtzitting dat de kans op recidive niet aanwezig is omdat zijn dochter heeft ingezien dat het

I32. Zie ook Ten Voorde, Cultuur als verweer, a.w., p. 62 e.v. en p. 293 e.v.

I33. Hof Arnhem I2 juni 2002, LJN: AE4029; vgl. ook Rechtbank Middelburg I5 oktober 2003, LJN: AL9045.

I34. Rechtbank II november 2005, LJN: AU599I; zie ook Rechtbank Alkmaar 4 maart 2008, LJN: BC5712; zie ook Hof's-Gravenhage 23 juni 2005, LJN: AUor8o.

I35. Rechtbank Haarlem 9 mei 200I, LJN: ABI503; zie ook Hof Arnhem 5 september 2002, LJN: AE7333; Hof's-Gravenhage 23 juni 2005, LJN: AUor8o; Hof Arnhem 6 juli 2005, LJN: AT8835. 
verkeerd is wat zij heeft gedaan [curs. HDW]. ${ }^{13}{ }^{6}$ De rechter dient zich er wel van te vergewissen dat de dader hier niet enkel een houding aanneemt - een houding die zelf ook weer cultuurbepaald kan zijn (niet verloochenen van de eigen cultuur).

\section{$9 \quad$ Afsluitende opmerkingen}

Een paar korte opmerkingen ter afsluiting. In deze bijdrage is geprobeerd te laten zien, aan de hand van diverse voorbeelden, hoe het Nederlandse strafrecht 'omgaat' met bepaalde culturele gedragingen. Daarmee is niet de vraag beantwoord of het Nederlandse strafrecht voldoende ruimte biedt voor het verwerken van de culturele achtergond van de dader en het delict. Die vraag kan per definitie niet aan de hand van dat recht zelf worden beantwoord. ${ }^{137}$ Maar ook de (neutrale) vraag welke ruimte het Nederlandse strafrecht in dit opzicht biedt, kan moeilijk in het algemeen beantwoord worden. De bespreking laat (hopelijk) wel zien welke vragen (kunnen) rijzen. Enkele betreffen specifieke wetgevingskwesties, bijvoorbeeld of meisjesbesnijdenis apart strafbaar gesteld dient te worden. Deels hebben zij betrekking op de erkenning van bepaalde culturele waarden en normen. Die spelen op wetgevingsniveau (wel of geen bijzondere regelingen) en op het niveau van de interpretatie van bestanddelen. Is bijvoorbeeld de huidige betekenis die aan delictsbestanddelen als 'eerbaarheid' of 'ontuchtige handelingen' wordt gegeven nog wel een wenselijke? Voor de strafuitsluitingsgronden geldt hetzelfde. Zoals De Hullu opmerkt, zal in dat kader 'ongetwijfeld [de vraag] gaan rijzen of niet te star aan traditionele cultuurwaarden wordt vastgehouden'. ${ }^{138}$ Bij met name psychische overmacht, in geval van ernstige delicten, speelt het punt of de rechter hier juist een extra strenge redelijkheidstoetsing moet uitvoeren vanuit rechtspolitieke overwegingen - overwegingen die ook bij de straftoemeting van belang zijn (generale preventie). En ten aanzien van deze twee onderwerpen is er natuurlijk de wezenlijke vraag wat cultuur 'doet' (in het concrete geval, bij deze persoon). Hier is heel duidelijk dat de vraag of het Nederlandse strafrecht voldoende ruimte biedt aan cultuur problematisch is. Die ruimte is er immers in die zin dat de Nederlandse rechter bij zowel psychische overmacht als de straftoemeting rekening kán houden met alle omstandigheden, dus ook met cultuurbepaalde invloeden (zoals ook met (Nederlandse) subcultuurbepaalde invloeden en met niet-cultureelbepaalde invloeden). Of hij dat in voldoende mate doet, ${ }^{\mathrm{I}}{ }^{39}$ hangt (mede) af van de vraag welke invloed cultuur op iemands handelen kan hebben.

136. Rechtbank Alkmaar 4 maart 2008, LJN: BC57I2. Vgl. ook Rechtbank Dordrecht 2I oktober 2003, LJN: AM2493. Ziet de dader inmiddels wel in dat zijn handelen ontoelaatbaar was, dan kan dat strafverlagend werken. Men denke aan het plegen van een zedendelict met een minderjarige waarbij het initiatief is uitgegaan van het kind (hetgeen aan de strafbaarheid niet afdoet). Zie bijvoorbeeld Rechtbank 's-Gravenhage I8 oktober 2004, LJN: AR5003: 'De kans op recidive wordt laag ingeschat nu de werking van het geweten intact is, opportunisme en interactie met het slachtoffer van belangrijke invloed zijn geweest en de detentie impact op verdachte heeft gesorteerd. Waarschijnlijk heeft een tekort aan inzicht betreffende seksuele waarden en normen een rol gespeeld, mogelijk samenhangend met culturele verwarring.'

I37. Vgl. Bovens, a.w., p. I48. Zie ook de vraag van Schuyts preadvies (a.w., p. 66): 'in hoeverre dient het Nederlandse recht ruimte te laten voor andere (rechts)culturen?'

138. De Hullu, a.w., p. 362 .

I39. Een negatief antwoord volgt natuurlijk nog niet uit het enkele gegeven dat een beroep op psychische overmacht ('vanwege de cultuur') tot dusverre nooit succesvol is geweest. 